MARIIA BILETSKA* - LUBLIN

\title{
KS. WLADYSLAW WANAGS MIC I JEGO POSŁUGA NA PODOLU W LATACH 1977-2001
}

\section{Wstęp}

Ksiądz Władysław Wanags to wybitny kapłan i polski patriota, choć o łotewskich korzeniach. Charakteryzował się dużą odwagą, niezłomną wiarą i ogromnym talentem organizacyjnym, dzięki czemu w okresie ZSRR i po jego upadku, skutecznie pracował duszpastersko. Do tej pory jego życie i działalność nie doczekały się jednak szerszego omówienia. Prezentowany artykuł jest próbą zapełnienia tej luki. Głównym źródłem wykorzystanym w artykule były świadectwa parafian z Gródka Podolskiego, gdzie pracował ks. Władysław. Przy analizie zebranych świadectw można było zauważyć, że relacje są do siebie bardzo zbliżone. Może to świadczyć o prawdziwości przekazanych informacji. Pomocnym dla autorki było także opracowanie ks. Stanisława Kurlandzkiego Panie, do kogoż pójdziemy?. We wspomnianym dziele umieszczona została krótka biografia ks. Wanagsa, powstała podczas z rozmowy z tym kapłanem. W pracy została wykorzystana dodatkowa literatura dotycząca podjętego tematu. Pomogła ona przybliżyć czasy komunistycznego terroru i sytuację Kościoła katolickiego oraz jego wiernych. Nie udało się dotrzeć do dokumentów archiwalnych, gdyż są one nadal niedostępne dla badaczy. Zapewne mogłyby one wzbogacić pracę o informacje poszerzające naszą wiedzę o życiu i działalności bohatera niniejszego artykułu.

\section{Kościół katolicki i jego rola w życiu mieszkańców państwa komunistycznego}

Kościół katolicki na ziemiach wschodnich dawnej Rzeczpospolitej był powszechnie uznawany jako Kościół polski. Oprócz roli religijnej, Kościół łaciński na tych terenach bronił, a także upowszechniał polskości. Stąd też był dla władz komunistycznych przeszkodą w sowietyzacji polskiego społeczeństwa ${ }^{1}$.

* Mariia Biletska - mgr historii; doktorantka w Instytucie Historii KUL; e-mail: maria. bilecka@op.pl

${ }^{1}$ J. Szymański, Rola Kościoła katolickiego i jego duchowieństwa na Ukrainie w zachowaniu wiary i tożsamości narodowej, „Archiwa Biblioteki i Muzea Kościelne”, 81 (2004) s. 327. 
W latach 20. XX wieku, większość katolików w państwie sowieckim stanowili Polacy. Szacuje się ich liczbę na $80 \%$. Poza Polakami były również niewielkie grupy Ukraińców, Białorusinów, Łotyszy oraz osób innych narodowości. Na Ukrainie żyło 650.000 Polaków, a na Białorusi 300.000, co w sumie daje 950.000 osób $^{2}$. Na początku lat 20. XX wieku partia komunistyczna oraz władze państwowe, publicznie obiecywały, że jedynie w ustroju socjalistycznym narody mają możliwość pełnego rozwoju swej kultury duchowej i materialnej. Rozwojem kultury wśród społeczności Polskiej miało się zająć specjalne Biuro Polskie, istniejące przy Komitecie Centralnym ${ }^{3}$. Władza utożsamiała katolicyzm obrządku łacińskiego z polskością, tak samo jak prawosławie z narodowością rosyjską. Dla władzy komunistycznej Polak był wrogiem ZSRR. Po dojściu do władzy bolszewików, ludność polska obawiając się represji, ukrywała swoje prawdziwe pochodzenie. W późniejszym okresie często zdarzało się, że chroniąc się przed deportacjami, Polacy podawali się za Ukraińców wyznania katolickiego, co często pozwalało uniknąć represji ze strony władz sowieckich ${ }^{4}$.

Prześladowania dotknęły bardzo mocno katolickie duchowieństwo m.in. usuwano księży z domów parafialnych, zmuszano do odbycia służby wojskowej w szeregach Armii Czerwonej. Częste były przypadki aresztowań oraz rozstrzelania duchownych bez sądu i śledztwa. Jako przestępstwo taktowano katechizację dzieci i młodzieży. Księży oskarżano o wykorzystywanie religii do obalenia rządu oraz budzenie zabobonów dla czerpania korzyści materialnych. Na podstawie Kodeksu Karnego ZSSR, każde niepożądane działanie duchowieństwa lub świeckich rozumiano jako czynność kontrrewolucyjną, za co groziło 10 lat więzienia, albo kara śmierci przez rozstrzelanie. Oskarżenia formułowane były na podstawie donosów obywateli, zawiadomień bolszewickich agentów, dokumentów partyjnych, archiwów, organizacji społecznych oraz zeznań aresztowanych ${ }^{5}$.

Ustawodawstwo karne, jak również środki masowego przekazu, były wykorzystywane do walki z duchowieństwem. Najpopularniejsza gazeta w Związku Sowieckim - „Bezbożnik” wychodziła codziennie od 1928 roku. Najczęściej jej nagłówki prezentowały treści ośmieszające w brutalny sposób wiarę oraz duchownych. Gazeta oskarżała ich o agitację społeczeństwa przeciwko rządowi sowieckiemu i podburzanie wiernych podczas spowiedzi, sprzeciwianiu się kolektywizacji, działaniu na rzecz Stanów Zjednoczonych albo Watykanu, a także w nielegalnym odprawianiu mszy i upowszechnianiu literatury katolickiej. Innym sposobem zniesławienia księży było tworzenie nieprawdziwych historii, np. o spotkaniach z kobietami, kradzieżach albo pijaństwie. Wszystko to miało na celu zniszczenie zaufania wiernych do kapłanów i Kościoła ${ }^{6}$.

\footnotetext{
${ }^{2}$ R. Dzwonkowski, Kościót katolicki w ZSSR 1917-1939. Zarys historii, Lublin 1997, s. 43.

${ }^{3}$ Polacy na Ukrainie. Zbiór dokumentów, cz. 1: lata 1917-1939, t. 1, red. S. Stępień, Przemyś1 1998, s. 8-9.

${ }^{4}$ Szymański, Rola Kościoła katolickiego i jego duchowieństwa na Ukrainie, s. 328.

${ }^{5}$ Tamże, s. 330-331.

${ }^{6}$ M. Biletska, Prześladowanie duchowieństwa katolickiego na Podolu w czasach sowieckich na przyktadzie ks. Jana Brydyckiego (1864-1937), w: Studia nad polityka polska XX wieku. Relacje państwo - Kościót, red. M. Ryba, Lublin 2016, s. 232.
} 
Na kapłanów nałożone były wysokie podatki osobiste oraz kościelne. Najbardziej uprzykrzała życie bezustanna inwigilacja komunistycznych szpiegów i donosicieli. Jednym z zarzutów wysuwanych pod adresem księży, było oskarżenie o przynależność do kontrrewolucyjnej organizacji POW (Polska Organizacja Wojskowa), która przestała istnieć jeszcze w 1918 roku. Dla bolszewików nie miało to znaczenia, chodziło tylko o wygodny pretekst do kolejnych ataków na duchownych. Dzięki temu władze mogły oskarżać księży o szerzenie wrogiej propagandy wśród ludności polskiej, pomoc w bezprawnym przekraczaniu granic ZSRR oraz o działalność szpiegowską. Wprowadzano za te czyny wysokie kary długoletniego więzienia, a także zsyłki na Syberię?.

Aby poderwać autorytet osób duchownych, rozpuszczano plotki o współpracy księży z czekistami. W celu uwiarygodnienia tych oszczerstw władze przeprowadzały aresztowania duchownych, których po jakimś czasie zwalniano, rozgłaszając informacje o podjęciu przez aresztowanych współpracy ze służbami państwowymi. Zwolnieni mogli jednak spodziewać się ponownego aresztowania w każdej chwili.

Oprócz aresztowań kapłanów, władze przeprowadzały masowe akcje zamykania świątyń. Wierni bowiem przychodzili do kościołów nawet wtedy, gdy nie było już przy nich duchownych. Wierzący masowo składali podania i listy do władz, w których prosili o zwolnienie aresztowanych kapłanów. Nieraz demonstrowali pod gmachami urzędów9 ${ }^{9}$. Świadczy to nie tyko o ich wyjątkowej odwadze, ale zachowaniu świadomości religijnej i narodowej. Reakcja rządu sowieckiego wobec takiej aktywności była bardzo surowa. Pełnomocnik ds. Religii stwierdzał, że listy Polaków noszą szkodliwy, polityczny charakter oraz wysyłane są przez „szpiegów watykańskich”"10.

Kapłani byli w tamtym czasie otaczani szczególną troską wiernych. Dlatego w planach władz, kolejnymi celami ataków byli parafianie. Wierni, którzy prowadzili aktywną działalność, nieukrywający swego polskiego pochodzenia, pierwsi stawali się ofiarami państwowego terroru: byli zsyłani do łagrów oraz rozstrzeliwani. Ze szczególną zaciekłością zwalczani byli członkowie „Żywego Różańca” z powodu swej aktywności oraz swej nieugiętej postawy ${ }^{11}$. Jednak ludzie młodzi, w obawie przed utratą pracy, nie zawsze podpisywali petycje kierowane do władz

${ }^{7}$ О. Пасечник, Другий етап гонінь римо-католицької Церкви на Поділлі у 20-30-х роках минулого століття, „Studia Catolica Podoliae”, s. 365-367.

8 R. Dzwonkowski, Represje wobec duchowieństwa katolickiego w ZSRR 1918-1939, w: Skazani jako „szpiedzy Watykanu”. Z kościoła katolickiego ZSRR 1918-1956, red. R. Dzwonkowski, Ząbki 1998, s. 24.

${ }^{9}$ Пасечник, Другий етап гонінь римо-католицької Церкви на Поділлі у 20-30-х роках, s. 368 .

${ }^{10}$ R. Dzwonkowski, Od Kościoła polskiego do Kościoła Polaków w krajach bytego ZSSR, „Przegląd Wschodni”, 5 (1998), z. 2, s. 285.

${ }^{11}$ Пасечник, Другий етап гонінь римо-католищької Церкви на Поділлі у 20-30-х роках, s. 371 . 
w sprawach Kościoła. Popierali postulaty i czekali na zmiany, kiedy można będzie otwarcie głosić swoją wiarę, nie ponosząc tego konsekwencji ${ }^{12}$.

Wojna niemiecko-sowiecka w 1941 roku spowodował trudną sytuację państwa sowieckiego, dlatego też władza złagodziła kurs antyreligijny. Sytuację wykorzystało zarówno duchowieństwo, jak i wierni. Zrodziło to możliwość wznowienia opieki duszpasterskiej na ogromnych terenach państwa sowieckiego ${ }^{13}$.

Trudno jest ustalić całkowitą liczbę represjonowanych duchownych katolickich różnych narodowości w Związku Sowieckim. Nie wydaje się możliwym, aby podać liczbę poszkodowanych kapłanów oraz wiernych świeckich, najczęściej pochodzenia polskiego, którzy w latach 1939-1987 byli represjonowani przez rząd ZSRS na ziemiach wschodnich przedrozbiorowej Rzeczypospolitej: Ukrainie, Zakarpaciu, Białorusi oraz w krajach bałtyckich. Nie ma także danych, o wysokości wyroków skazujących na zesłanie lub śmierć, gdyż były one wydawane często bez rozprawy sądowej i śledztwa. Posiadane informacje dotyczą około $90 \%$ aresztowanych i skazanych ${ }^{14}$.

Źródła zgromadzone do tej pory, umożliwiają jednak ustalenie ogólnej liczby represjonowanych duchownych oraz świeckich Kościoła katolickiego obrządku łacińskiego. Najliczniejsze grupy stanowią kolejno: Polacy, Litwini, Łotysze oraz Niemcy. Poza tym wśród represjonowanych byli: Ukraińcy, Białorusini, Słowacy, Rosjanie, Węgrzy, Włosi i Francuzi. Okresem największego nasilenia terroru i represji wobec kapłanów oraz wiernych Kościoła katolickiego obrządku łacińskiego, pozostających na terenach ZSRS, były lata 1945-1954. Na mocy umów jałtańskich, zostały przeprowadzone głębokie zmiany społeczne w postaci kolektywizacji, wywłaszczeń, likwidacji instytucji kościelnych na ziemiach włączonych do ZSRS. W tym czasie represje miały przede wszystkim postać aresztowań oraz wyroków skazujących na łagry, gdyż od maja 1947 roku kara śmierci została zawieszona. Warunki życia w łagrach i więzieniach powodowały ogromną śmiertelność więźniów ${ }^{15}$.

Po zakończeniu II wojny światowej na terytorium ZSRR na skutek przesunięcia granic, znalazło się ponad 800 parafii Kościoła katolickiego z ziem II Rzeczpospolitej. Wskutek szybkiej likwidacji wszystkich struktur kościelnych, z tej liczby do 1984 roku zostało około 100 parafii. W drugiej połowie lat $80 \mathrm{XX}$ wieku, kiedy zmieniła się sytuacja polityczna, nastąpiło pewne złagodzenie polityki wyznaniowej. Dało to możliwość stopniowej odbudowy struktur kościelnych ${ }^{16}$.

\section{Młodość i pierwsze lata kapłaństwa}

Władysław Wanags urodził się 4 kwietnia 1931 roku, w katolickiej rodzinie Pawła Wanagsa i Luci z domu Szumska, we wsi Strody na Łotwie, w rejonie Kra-

${ }^{12}$ Dzwonkowski, Polacy w Kościele katolickim, s. 57.

${ }^{13}$ Szymański, Rola Kościoła katolickiego i jego duchowieństwa na Ukrainie, s. 332.

${ }^{14}$ R. Dzwonkowski, Represje władz sowieckich wobec duchowieństwa katolickiego obrzadku tacińskiego w latach 1939-1987, „Przegląd Wschodni”, 7 (2000) z.1, s. 291.

${ }^{15}$ Tamże, s. 292.

${ }^{16}$ Odrodzenie Kościoła katolickiego w byłym ZSRR. Studia historyczno-demograficzne, red. E. Walewander, Lublin 1993, s. 89. 
sławskim. Ojciec Władysława Wanagsa był Łotyszem jednak polskiego pochodzenia. Razem z żoną wychowywali jeszcze dwóch synów ${ }^{17}$. Podstawą utrzymania rodziny było 34-hektarowe gospodarstwo rolne. Wiara odgrywała ważną rolę życiu rodziny. Co niedziela Wanagsowie udawali się do kościoła na mszę św. Paweł Wanags pragnął, aby jeden z jego synów wybrał kapłaństwo. Gdy W. Wanags miał 6 lat, zmarła matka. Ojciec ożenił się po raz drugi, rok później. Macocha nie żywiła sympatii do przybranego syna i jak twierdził sam Władysław - zawsze był względem niej nieposłusznym buntownikiem ${ }^{18}$.

Po ukończeniu szkoły powszechniej, Władysław Wanags pracował w rodzinnym gospodarstwie rolnym. W latach 1947-1952 służył w armii radzieckiej w Gwardziejsku, w obwodzie kaliningradzkim. Po odbyciu pięcioletniej służby wojskowej w lekkiej artylerii, ukończył szkolę wojskową ze stopniem starszego sierżanta. W trakcie służby w wojsku W. Wanags ożenił się z Rosjanką. Przeprowadził się do miasta Jełgawa koło Rygi, gdyż po służbie wojskowej otrzymał tam ziemię. Miłość do pracy na roli, którą wyniósł z domu rodzinnego, na zawsze pozostała w sercu Władysława. Niebawem urodziła mu się córka Lucja. Natomiast w 1961 roku, kiedy urodziła się córka Rita, Władysław wybudował dla rodziny dwupiętrowy dom. Pracował wówczas jako kierownik transportu w zakładach produkujących maszyny rolnicze ${ }^{19}$. W tym czasie W. Wanags bardzo ciężko zachorował. Lekarze byli bezradni gdyż nie mogli zdiagnozować przyczyn schorzenia. Władysław zaczął wówczas modlić się o cud uzdrowienia. Jak sam wspominał później: „Niebiańska Matka otworzyła dla mnie Boga”. Na skutek uzdrowienia i związanej z tym przemiany duchowej, przystąpił do sakramentu spowiedzi oraz zaczął prawie codziennie chodzić do kościoła na msze św. Przemiana Władysława doprowadziła szybko do konfliktów z żoną, która była przeciwna, aby córki chodziły do kościoła z ojcem. Dodatkowo okazało się z czasem, że żona Władysława zanim go poznała, była już zamężna. Fakt ten zataiła, co oznaczało, że małżeństwo zawarte przez Wanagsów było nieważne. Niebawem z inicjatywy Władysława rozwiedli się, a była żona zabrała dzieci i wyjechała do Rosji. Ks. Władysław Wanags po latach stwierdził:

Szczęście w nieszczęściu. Moje ślepe oczy otworzyły się na świat i Boga, wiara stała się ratunkiem dla mojej duszy ${ }^{20}$.

W 1967 roku Władysław Wanags zaczął pracować jako kościelny oraz śpiewać w chórze w kościele pw. św. Franciszka w Rydze. Zwrócił na niego uwagę dziekan, który był rektorem Wyższego Seminarium Duchownego w Rydze. Właśnie to on pierwszy zobaczył w Władysławie przyszłego księdza. Sam Wanags

${ }^{17}$ N. Szpyczko, Kościoły i sanktuaria. Ksiądz Władysław Wanags - budowniczy 29 kościołów rzymskokatolickich na Podolu, „Rota”, 1 (2004) s. 61.

${ }^{18}$ N. Szpyczko, W. Rożkow, Ojciec Władysław Wanags MIC - siewca żywej wiary na Podolu w okresie radzieckiego totalitaryzти, w: Славістичні студія: лінгвістика, літературознавство, дидактика. Збірник наукових праць, ред. Н.В. Подлевска, Хмельницький-Люблін 2015, s. $257-$ 258.

${ }^{19}$ Relacja ustna Genadiusza Bileckiego ze wsi Słobódka Rachnowiecka, z dnia 28 XI 2015 r.; w zbiorach autorki.

${ }^{20}$ Cyt. za: Szpyczko, Rożkow, Ojciec Władysław Wanags MIC, s. 258. 
też myślał o wstąpieniu do seminarium, jednak przeżywał duże rozterki. Obawiał się także, że przeszkodą w podjęciu studiów będzie jego wiek oraz brak wykształcenia ${ }^{21}$.

Po przezwyciężeniu obaw, w 1968 roku rozpoczął studia w Wyższym Seminarium Duchownym w Rydze ${ }^{22}$. Aby podjąć studia w seminarium każdy kandydat musiał mieć zezwolenie od KGB. Wiązało się to $\mathrm{z}$ wyrażeniem zgody na współpracę z bezpieką. Tak zwane współdziałanie $\mathrm{z}$ władzą sowiecka było proponowane każdemu kandydatowi. Jeśli ze strony pretendenta do kapłaństwa padła odmowa na powyższy warunek, wówczas nie dostawał pozwolenia na podjęcie edukacji w seminarium. Ponieważ władze państwowe wyznaczały bardzo niską liczbę przyjmowanych studentów, chętni do podjęcia studiów w seminarium czekali nieraz ponad 10 lat, co prowadziło często do rezygnacji ze swoich zamiarów ${ }^{23}$. Kandydatom starano się również uniemożliwić naukę w seminarium, piętrząc inne trudności, np. posiadanie rodziny za granicą, działalność członka rodziny czy krewnego w partyzantce w czasie wojny, pochodzenie z rodziny ziemiańskiej itp. Wspomniane przeszkody, były przyczyną powstania tajnych studiów seminaryjnych, gdzie kleryk mógł uczyć się jedynie w konspiracji i również w taki sposób przyjąć święcenia kapłańskie ${ }^{24}$.

Gdy W. Wanags spotkał się z pracownikami KGB, w celu otrzymania zgody na wstąpienie do seminarium, nie otrzymał od razu pozwolenia. Zaproponowano mu natomiast pełnienie funkcji zakrystianina, zamiast podjęcia studiów ${ }^{25}$. Władysław Wanags argumentował swoją decyzję słowami: „To jest wola Boża, i muszę ją wypełnić. Nie mogę sprzeciwiać się Bogu". Jego stanowczość i przekonanie o słuszności wyboru drogi kapłańskiej były tak przekonywujące dla władz, że dostał zgodę na wstąpienie do seminarium, nie podejmując współpracy z KGB ${ }^{26}$.

W tym czasie wspólnotę Wyższego Seminarium Duchownego w Rydze stanowiło 14 kleryków i kilku profesorów. Dobra atmosfera seminarium pozytywnie wpływała na kandydatów do kapłaństwa. Jak wspominał ks. Władysław Wanags:

Kiedy ks. Piotr Upiniek, marianin, profesor teologii moralnej, serdecznie mnie przywitał i tchnął nadzieję $\mathrm{w}$ serce, wtedy poczułem się - mimo starszego wieku - $\mathrm{u}$ siebie. To on troszczył się o mnie przez najbliższe cztery lata i dużo się modlił w mojej intencji. Ten kapłan tak mnie umiłował, że wlewał do mojej duszy Ducha Bożego ${ }^{27}$.

Po czterech latach studiów Wanagsa w seminarium, ks. Upiniek zmarł, a na jego miejsce przyszedł o. Viktors Pentjušs ${ }^{28}$, który potajemnie prowadził w se-

${ }^{21}$ Kurlandzki, Danilecka, Panie, do kogoż, s. 223.

${ }^{22}$ W ZSRS funkcjonowały tylko dwa seminaria katolickie - w Rydze (Lotwa) i Kownie (Litwa).

${ }^{23}$ Szpyczko, Rożkow, Ojciec Władysław Wanags MIC, s. 259.

${ }^{24}$ Relacja ustna Genadiusza Bileckiego ze wsi Słobódka Rachnowiecka, z dnia 28 XI 2015 r.; w zbiorach autorki.

${ }^{25}$ Tamże.

${ }^{26}$ Kurlandzki, Danilecka, Panie, do kogoż, s. 224.

${ }^{27}$ Tamze, s. 223.

${ }^{28}$ Viktors Pentjušs - ur. 7 IX 1915 r. w Meza Vepri, w parafi Rundani na Łotwie, w katolickiej rodzinie Adama i Zofii z domu Uzuls. W 1931 r. został przyjęty do Zgromadzenia Marianów 
minarium mariański nowicjat ${ }^{29}$. Właśnie tutaj Władysław poznał charyzmat Zgromadzenia Księży Marianów i zapragnął wstąpić w jego szeregi. Rys maryjny był później bardzo silny w jego działalności duszpasterskiej, co przejawiało się m.in. głoszeniem hasła: Maryja - królowa świata ${ }^{30}$. W. Wanags przyjął święcenia kapłańskie w dniu 2 sierpnia 1973 roku $^{31}$ z rąk biskupa Valerijansa Zondaksa ${ }^{32}$. O. Viktors Pentjušs natomiast przyjął Wanagsa do marianów.

w Welonach koło Vilani, gdzie odbył nowicjat oraz złożył 25 maja 1931 r. pierwszy śluby zakonne. Przez pięci lat uczył się jako eksternista w katolickim gimnazjum w Agłonie. W roku 1937 rozpoczął studia w seminarium duchownym w Rydze, które następnym roku zostało przekształcone na Wydział Teologii Katolickiej miejscowego uniwersytetu. W dniu 9 marca 1942 roku przyjął święcenia kapłańskie z rąk bpa J Rancansa. Pracę duszpasterską rozpoczął w parafii Welony jako wikariusz, a w latach 1941-1947 jako proboszcz. Na żądanie władz państwowych został przeniesiony do Kurzemy w Kurlandii, gdzie był proboszczem parafii Lamini i Tukums. Obsługiwał również parafie: Kandava i Zante. Został aresztowany 25 października 1948 r. w parafii Tukums i uwięziony w Rydze, gdzie po 4 miesiącach śledztwa, został skazany w dniu 5 marca 1949 roku zapadł wyrok 10 lat łagrów za pomoc niemieckiemu okupantowi oraz prowadzenie antysowieckiej propagandy. Wywieziono go do łagru w Workucie. Zwolniony został po ośmiu latach łagrów i powrócił na Łotwę. Po krótkiej rehabilitacji zdrowotnej we wrześniu 1956 r., rozpoczął pracę duszpasterską w parafii Lamini w Kurlandii, a przez cztery kolejne lata w Welony. Władze państwowe zmusiły go do wyjazdu do Kurlandii, gdzie pracował w parafiach: Arlava-Ciruli, Sadus, Salaine, Grendze i Eglaine. W 1972 r. został ojcem duchownym w seminarium ryskim, gdzie wykładał również teologię moralną. Równocześnie był proboszczem katedry św. Jakuba w Rydze. W 1991 r. został pełnomocnym wicerektorem seminarium, a w 1996 r. wikariuszem parafii Matki Boskiej Bolesnej w Rydze, która była pod opieką Zgromadzenia Marianów. Dodatkowo prowadził archidiecezjalne studium katechetyczne dla osób świeckich. Data śmierci ks. Viktorsa Pentjušsa nie jest znana. Oprac. na podstawie: R. Dzwonkowski, Viktors Pentjušs, w: Leksykon duchowieństwa Polskiego represjonowanego w ZSRR 1939-1988, Lublin 2003, s. 469-470.

${ }^{29}$ Szpyczko, Rożkow, Ojciec Władystaw Wanags MIC, s. 260.

${ }^{30}$ Relacja ustna Genadiusza Bileckiego ze wsi Słobódka Rachnowiecka, rej. Dunajowiecki, obw. Chmielmicki, Ukraina; w zbiorach autorki.

${ }^{31}$ Szpyczko, Rożkow, Ojciec Władystaw Wanags MIC, s. 260.

${ }^{32}$ Valerijans Zondaks - ur. się 2 V 1908 r. w parafii Vilakas w Łatgalii. Skończył gimnazjum w Agłonie, po którym wstąpił do seminarium duchownego w Rydze. W dniu 8 maja 1932 r. przyjął święcenia kapłańskie. Był wikariuszem w Agłonie przez 8 lat. Dodatkowo wykładał astronomię i fizykę w miejscowym gimnazjum. Równolegle był studentem Uniwersytetu w Rydze, gdzie w 1937 r. uzyskał stopień magistra matematyki. W okresie okupacji sowieckiej (1940-1941) i niemieckiej (1941-1944) był proboszczem w Łatgalii. W 1944 r. został proboszczem parafii Barkavas oraz ponownie wykładowcą w gimnazjum w Agłonie. W latach 1946-1953 był profesorem w seminarium duchownym w Rydze oraz wikariuszem w kościele seminaryjnym pw. św. Franciszka z Asyżu. W późniejszym czasie został mianowany proboszczem kościoła katedralnego św. Jakuba. Dodatkowo był notariuszem Kurii Biskupiej w Rydze, a później jej kanclerzem. Został aresztowany w 1953 r. i skazany na 25 lat łagrów. Po trzech latach został zwolniony i powrócił na Łotwę. Był jeszcze dwukrotnie aresztowany, a w łagrach i więzieniach spędził łącznie 6 lat i 7 miesiące. Po wyjściu na wolność pracował jako profesor w seminarium duchowym oraz wikariusz w kościele seminaryjnym w Rydze. W latach 1960-1963 był proboszczem parafii w Naglu, a później przez 3 lata w Vidżmuivas. Od 1969 r. do 1986 r. był rektorem seminarium duchownego w Rydze. Konsekrowany na biskupa konsekracja w katedrze pw. św. Jakuba w dniu 12 XI 1972 r. Zmarł 
W roku 1975 ks. Władysław złożył swoje pierwsze śluby zakonne w zgromadzeniu, a w 1979 roku - śluby wieczyste.

Po święceniach kapłańskich ks. Władysław został skierowany do parafii w Varakjani w Ładgalii, gdzie pracował jako wikariusz. Niedaleko znajdowały się mariańskie klasztory w Vilāni i Rēzekne, a także w Liepaja - mieście portowym nad Morzem Bałtyckim. Praca wśród wiernych sprawiała ks. Wanagsowi wielką radość, a parafianie bardzo go szanowali i cenili.

Następną placówką duszpasterską była Lipawa w Kurlandii. Wielu mieszkańców miasta było ateistami, którzy nienawidzili religii i wszystkiego, co z nią związane. Władze lokalne utrudniały duchowieństwu wykonywanie obowiązków duszpasterskich. Zabroniono m.in. odprowadzania zmarłych z krzyżem na cmentarz oraz ustawiania krzyża na mogiłach ${ }^{33}$. Z inicjatywy ks. Wanagsa i na jego koszt, stolarz wykonał kilka krzyży nagrobnych oraz duży krzyż procesyjny. Od tej pory procesje pogrzebowe odbywały się już z krzyżem na czele. Ludność katolicka początkowo miała wielkie obawy wobec działań swego kapłana. Jednak z czasem, widząc poświęcenie oraz wielką wiarę i odwagę ks. Władysława wierni zaufali odważnemu marianinowi.

Ks. Wanags o godzinie 7.00 odprawiał mszę św. bez śpiewu i organisty, tak zwaną cichą. Uczestniczyło w niej zwykle kilku wiernych. Jednak osobowość oraz styl duszpasterski ks. Władysława zaczęły zjednywać mu coraz większe rzesze słuchaczy. Natomiast msze św. odprawiane przez proboszcza gromadziły coraz mniej parafian. Pewnego dnia zaskoczony prałat spytał ks. Władysława: „Co ksiądz robi?” On odpowiedział: „Ja tylko dzielę się z wiernymi refleksjami o tajemnicach dnia liturgicznego" 34 .

Działalność ks. Wanagsa oraz jego rosnąca popularność wśród wiernych, zaniepokoiły miejscowe władze. $Z$ tego powodu, $z$ inicjatywy proboszcza, i za zgodą arcybiskupa Juliansa Vaivodsa ${ }^{35}$ ks. Wanags został przeniesiony do Gródka

27 września 1986 r. Oprac. na podstawie: R. Dzwonkowski, Valerijans Zondaks, w: Leksykon duchowieństwa Polskiego, s. 675.

${ }^{33}$ Tamże, s. 260

${ }^{34}$ Cyt za: Kurlandzki, Danilecka, Panie, do kogoż, s. 224.

35 Julians Vaivods - ur. 18 VIII 1895 r. we wsi Biernany w gminie Varkava w Łatgalii, w rodzinie chłopskiej. Był najstarszym spośród sześciorga dzieci. Po zakończeniu szkoły podstawowej w Varkavie, rozpoczął naukę w czteroletniej szkole realnej w Preilach. Uzyskał świadectwo lojalności, które było wymagane przez władze carskie, aby mógł wstąpić do seminarium. W 1913 r. wstąpił do seminarium duchownego w Petersburgu. W 1918 r. Otrzymał święcenia kapłańskie i został wikariuszem w Agłonie. W 1920 r. rozpoczął pracę jako wikariusz w Rzeżycy, a po niej w parafii Łudze. Zajmował się katechizacją dzieci w szkołach. Opracował i wydał kilka książek dotyczących prawd wiary w języku łotewskim. W 1924 r. opublikował w języku łatgiewskim Krótki zarys dogmatyki. W 1927 r. został wikariuszem w parafii Varaklany, a następnie proboszczem w parafii Leny w Kurlandii, gdzie katolicy byli prześladowani przez luteran. Ks. Vaivods założył tam parafie: Salda, Ceciere i Vainody. Pracował jako proboszcz w parafii Asunga, Vindava oraz Jaunielgava. W 1939 r. został kanclerzem kurii biskupiej diecezji Libawa. Studiował na Uniwersytecie w Rydze na Wydziale Teologii Katolickiej. W 1943 r. otrzymał stopień licencjata. W latach 1944-1948 był wikariuszem generalnym, równocześnie proboszczem katedry w Libawie. Aresztowany 2 I 1958 r. po znalezieniu w jego mieszkaniu książek i rękopisów 
Podolskiego na Ukrainie. Ordynariusz uzasadnił to przeniesienie faktem zamieszkania w miasteczku około sześciuset Polaków, którzy chcą regularnie uczęszczać do spowiedzi i komunii św., szczególnie w pierwsze piątki miesiąca. Ks. Wanags argumentował, że nie zna języka polskiego, na co arcybiskup mu odpowiedział: „To dobrze, będziesz mniej mówił. Wyjedź jutro, zarzuć tam kotwicę i wracaj, aby się stąd wymeldować"36.

\section{W Gródku Podolskim}

Działalność ks. Władysława Wanagsa była dobrze znana nie tylko w parafii, w której pracował, lecz również w całej diecezji kamienieckiej. Powstanie diecezji w Kamieńcu Podolskim przypada na lata 1378-1386. Inicjatorem był Kazimierz Wielki, król polski, lecz projekt założenia biskupstwa zatwierdził Ludwik Węgierski ${ }^{37}$. Kamieniec zamieszkiwany był przez Polaków, Rusinów, Ormian, którzy przynależeli do wielu wyznań. W 1570 roku miasto składało się z 645 domów, a w XVIII stuleciu liczyło już ponad 12.000 mieszkańców, reprezentujących trzy wyznania: katolickie, prawosławne i ormiańskie. Rzymscy katolicy stanowili ponad jedną trzecią mieszkańców. Kamieniec z kościołem katedralnym pw. św. Piotra i Pawła był stolicą diecezji. Za fundatorów katedry uważano książąt Koriatowiczów. Za datę powstania kościoła katedralnego powszechnie przyjmuje się rok 1375. Była ona najważniejszą świątynią w diecezji kamienieckiej, gromadzącą wokół siebie dużą liczbę stowarzyszeń świeckich oraz duchowieństwa ${ }^{38}$. Diecezja kamieniecka przynależała początkowo do metropolii halickiej, a w roku 1412 podporządkowana została metropolii lwowskiej. W roku 1867, w rezultacie represji po powstaniu styczniowym, diecezja kamieniecka została zlikwidowana przez cara Aleksandra $\mathrm{II}^{39}$.

Duchowieństwo i wierni na Podolu nie zaprzestali starań o reaktywowanie diecezji oraz obsadzenie stolicy biskupiej w Kamieńcu Podolskim. Udało się to dopiero po 1905 roku, kiedy car Mikołaj II ogłosił ukaz tolerancyjny O umocnieniu zasad wolności religijnej. Dekret ten gruntownie zmienił sytuację wyznawców wszystkich religii w imperium rosyjskim. Jednak wkrótce władze carskie

uznanych za antypaństwowe i skazany na dwa lata łagrów. Po odbyciu wyroku, przez rok czekał na rejestrację w parafii Vianoda. W 1961 r. został administratorem katedry pw. św. Jakuba w Rydze, a w następnym - wikariuszem generalny archidiecezji ryskiej. Święcenia biskupie przyjął 18 XI 1964 r. został w Bazylice św. Piotra w Rzymie. Równocześnie został administratorem apostolskim archidiecezji ryskiej i diecezji libawskiej. W 1983 r. otrzymał kapelusz kardynalski. Żył w przyjaźni z innymi wyznaniami chrześcijańskimi na Łotwie. Wyróżniony przez Moskiewskiego Patriarchę Prawosławnego Orderem św. Włodzimierza I oraz II stopnia. Władze państwowe wyróżniły go dyplomem uznania Rady Ministrów a także medalem Łotewskiego Komitetu Obrońców ŁSRR Pokoju. Był dobrym kaznodzieją i pozostawił po sobie prace naukowe z historii Kościoła katolickiego na Łotwie. Zmarł w Rydze 23 V 1990 r. Pochowany został przy kościele w Agłonie. Dzwonkowski, Leksykon duchowieństwa Polskiego, s. 609-610.

${ }^{36}$ Cyt. za: Kurlandzki, Danilecka, Panie, do kogoż, s. 225.

${ }^{37}$ Dzwonkowski, Polacy w kościele katolickim, s. 201.

${ }^{38}$ Mucha, Organizacja diecezji kamienieckiej do 1795 roku, s. 95.

${ }^{39}$ Dzwonkowski, Polacy w kościele katolickim, s. 201. 
ponownie ograniczyły swobodę wyznaniową. W tej sytuacji, w 1907 roku, za wiedzą i poparciem bpa Karola Niedziałkowskiego, jako administratora apostolskiego diecezji kamienieckiej, wierni wystosowali memoriał do papieża Piusa X, w którym apelowali o obsadzenie stolicy biskupiej w Kamieńcu. Petycja była poparta podpisami ponad 50.000 osób z obszaru całej diecezji. Z listem pojechał do Rzymu ks. Kazimierz Nosalewski ${ }^{40}$. Jednak petycja nie przyniosła oczekiwanych skutków. Do 1918 roku diecezja kamieniecka była administrowana przez biskupów łucko-żytomierskich ${ }^{41}$. Dopiero w czerwcu 1918 roku reaktywowano diecezję i powierzono ją ks. Piotrowi Mańkowskiemu ${ }^{42}$.

${ }^{40}$ Nosalewski Kazimierz - ur. 12 II 1872 r. w Smotryczu na Podolu. Szkołę powszechną ukończył w Kamieńcu Podolskim, seminarium duchowne w Żytomierzu. Święcenia kapłańskie otrzymał w 1898 r. Pracował duszpastersko w Barze, Ternówce, Kamieńcu Podolskim oraz Proskurowie (Chmielnicki), gdzie przez 17 lat pełnił funkcję proboszcza. W roku 1909 r. sprowadził do Proskurowa bezhabitowe Zgromadzenie Córek Najświętszego Serca NMP. W latach 1908-1910 wybudował kościół w Proskurowie, który został później zniszczonyprzez władze sowieckie. Ks. Nosalewski zorganizował liczne szkoły polskie na Podolu. Słynął z działalności charytatywnej. Rok po odrodzeniu diecezji kamienieckiej, w dniu 26 sierpnia 1919 r., objął rządy w w diecezji z powodu nieobecności ordynariusza bpa Piotra Mańkowskiego. Ks. Nosalewski był prześladowany przez władze sowieckie, m.in. dwukrotnie go aresztowano. Groziło mu rozstrzelanie, od którego uratowało go wstawiennictwo parafian. W latach 20. był rektorem Niższego Seminarium Duchownego, utworzonego przez bpa P. Mańkowskiego. Ostatnie lata życia spędził na terenie diecezji łuckiej. W 1932 r. był proboszczem w Żdołbunowie, a następnie w Szumku (1934-1935). Ostatnim miejscem pracy był Poczajów. Zmarł 6 II 1936 r. Oprac. na podstawie: Dzwonkowski, Losy duchowieństwa, s. 373-374.

${ }^{41}$ Rosowski, Dzieje rzymskokatolickiej, s. 45-46.

${ }^{42}$ Piotr Mańkowski - ur. 1 XI 1866 r. w Sachince na Podolu, jako siódmy oraz najmłodszy syn Walerego i Tekli z domu Łaźniewska. Dzieciństwo spędził na Podolu. W 1871 r. zmarł jego ojciec. Piotr wraz matką i rodzeństwem przeprowadzili się wówczas do Drezna w Saksonii. Tam rozpoczął naukę, najpierw w domu, a w 1881 r. poszedł do szkoły. W 1885 r. uzyskał świadectwo dojrzałości. Na krótki czas zamieszkał w Warszawie, po czym w 1885 r. rozpoczął studia agronomiczne na Uniwersytecie Wrocławskim. Po nauce zajął się gospodarowaniem na rodzinnych włościach, lecz nie przynosiło mu to satysfakcji. W 1896 r. przekazał posiadłości ziemskie bratu, a sam wstąpił do Seminarium Duchownego w Żytomierzu. P. Mańkowski ze względu na posiadanie matury, został przyjęty od razu na drugi rok kursu seminaryjnego. W dniu 27 VII 1899 r., przyjął święcenia kapłańskie w kościele parafialnym w Czerniowcach. Przez dziewięć lat był wikariuszem w parafii katedralnej w Żytomierzu. Studiował w Rzymsko-Katolickiej Akademii Duchowej w Sankt Petersburgu, starając się uzyskać stopień naukowy. Obowiązki kapłańskie wypełniał starannie, lecz największą trudność sprawiało mu głoszenie kazań, gdyż nie miał talentu oratorskiego. W 1911 r. ks. Mańkowski podjął pracę w kurii biskupiej, ponieważ władze rosyjskie zabroniły mu pracy duszpasterskiej. Wybuch I wojny światowej zastał go w Krakowie, skąd nie mógł wrócić do Żytomierza. Prowadził jednak aktywną działalność na rzecz Kościoła katolickiego na Wołyniu, gdzie w roku 1917 został upoważniony jako wikariusz generalny na czasowe objęcia jurysdykcji tamtej diecezji. W dniu 24 września 1918 roku ks. P. Mańkowski został powołany na biskupa kamienieckiego. Konsekracja biskupia odbyła się w październiku, w katedrze krakowskiej. Dopiero po zajęciu Podola przez wojska polskie w 1919 r. biskup mógł przybyć do swej diecezji. Zamieszkał w Kamieńcu Podolskim 6 XII 1919 r. Gdy w 1920 r. teren diecezji zajęli bolszewicy, ordynariusz wyjechaŁ do Buczacza, a następnie do Włodzimierza Wołyńskiego. W tym mieście spędził ostatnie lata życia. Bp P. Mańkowski zmarł 8 IV 1933 r. Pochowany został w krypcie katedry łuckiej. W 
Dnia 26 sierpnia 1919 roku Piotr Mańkowski przyjął per prokuram władzę nad Kościołem katolickim w diecezji kamieniecko-podolskiej. Na początku ordynariusz rządził za pośrednictwem ks. Kazimierza Nosalewskiego. W dniu 8 grudnia 1919 roku po raz pierwszy Piotr Mańkowski jako biskup uroczyście wkroczył do katedry kamienieckiej ${ }^{43}$.

Jednak wierni mogli się cieszyć obecnością biskupa tylko pół roku, gdyż na skutek ofensywy bolszewickiej, 5 lipca 1920 roku ordynariusz musiał opuścić Kamieniec. Zastępcą biskupa na czas jego nieobecności został ks. Jan Świderski ${ }^{44}$, powołany na stanowisko administratora apostolskiego diecezji kamienieckiej. Sprawował powierzone mu rządy do roku $1930^{45}$. Od tej pory diecezja kamieniecka została faktycznie bez kierownictwa. Najwyższy urząd w diecezji do roku 1937 sprawował dziekan bałcki ks. Antoni Wedegis, który był proboszczem parafii w Rybnicy. Był on represjonowany przez władze państwowe, które utrudniały mu pracę duszpasterską m.in. w 1936 roku dostał zakaz opuszczenia parafii ${ }^{46}$.

Latem 1944 roku bp łucki Adolf Szelążek mianował ks. Adolfa Kukuruzińskiego wikariuszem generalnym dla terenów dawnej diecezji kamienieckiej. Kapłan ten udał się natychmiast na terytorium swojej diecezji ${ }^{47}$. Już 28 grudnia tegoż roku został aresztowany przez NKWD. W trakcie procesu został oskarżony o zbieranie informacji o sytuacji ekonomiczno-politycznej obwodu kamienicko-podolskiego, szerzenie wiary katolickiej oraz przekazywanie nielegalnie informacji bp

czasie okupacji sowieckiej po 1939 r., zwłoki ordynariusza kamienieckiego były wielokrotnie profanowane. Oprac. na podstawie: K.R. Prokop, Biskupi kamienieccy od średniowiecza do współczesności. Szkice biograficzne, Biały Dunajec-Ostróg 2007, s. 354-364; J. Wołczański, Listy biskupa Piotra Mańkowskiego do arcybiskupa Józefa Bilczewskiego z lat 1912-1922, w: Pasterz i twierdza. Księga jubileuszowa dedykowana księdzu biskupowi Janowi Olszańskiemu ordynariuszowi diecezji w Kamieńcu Podolskim, red. J. Wołczański, Kraków-Kamieniec Podolski 2001, s. 401-407.

${ }^{43}$ Rosowski, Dzieje rzymskokatolickiej, s. 56-57.

${ }^{44}$ Świderski Jan - ur. 27 XII 1888 r. w Bałcie na Podolu. Ukończył szkołę średnią w Odessie. W 1926 r. rozpoczął studia w Seminarium Duchownym w Żytomierzu. Stamtąd został skierowany na studia w Akademii Duchownej w Petersburgu, których nie ukończył ze względu na stan zdrowia. Święcenia kapłańskie przyjął 17 XII 1912 r. w Żytomierzu. Został wikariuszem w Żmerynce. Od 1920 r. został proboszczem w Żińkowcach. W 1920 roku pełnił funkcję administratora apostolskiego diecezji kamienieckiej. Zarządzał diecezją pod nieobecność bpa P. Mańkowskiego. W 1921 r. został proboszczem w Barze, gdzie pracował osiem lat. Był prześladowany przez władze sowieckie. Aresztowany, otrzymał wyrok 10 lat łagrów i 5 lat pozbawienia praw obywatelskich. Został zwolniony $\mathrm{z}$ więzienia na skutek wymiany więźniów politycznych pomiędzy ZSSR a Polską. Po uwolnieniu ks. Swiderski pracował w diecezji łuckiej. W 1939 r. wyjechał do Warszawy. Od 1944 r. rozpoczął pracę w diecezji włocławskiej, w parafii Kościelec Kolski. Zmarł 18 X 1959 r. Oprac. na podstawie: Dzwonkowski, Losy duchowieństwa, s. 477-478.

${ }^{45}$ Dzwonkowski, Polacy w kościele katolickim, s. 201.

${ }^{46}$ Rosowski, Dzieje rzymskokatolickiej, s. 98.

${ }^{47}$ R. Dzwonkowski, Odrodzenie Kościoła Katolickiego na Ukrainie Środkowej, Potudniowej i Wschodniej w czasie II wojny światowej i bezpośrednio po jej zakończeniu (1941-1948), w: Pasterz i twierdza, red. J. Wołczański, Kraków-Kamieniec Podolski 2001, s. 27; W. Osadczy, Kościót katolicki na Ukrainie wobec represji sowieckich, w: Represje wobec Kościoła w krajach bloku wschodniego. Komuniści wobec religii po 1944 roku, red. J. Marecki, Kraków 2011, s. 87. 
Szelążkowi. Ks. Kukuruziński miał być tajnym agentem Watykanu działającym na szkodę państwa. Początkowo prokurator zażądał dla podsądnego kary śmierci, 5 maja 1946 roku skazano oskarżonego na 10 lat łagru. Wyszedł na wolność wiosną 1955 roku, a w 1957 roku został deportowany na terytorium Polski ${ }^{48}$.

Przez prawie 71 lat diecezja kamieniecka nie miała ordynariusza. O tym okresie mówi się w dziejach diecezji jako „owczarni bez pasterza”. Sytuacja Kościoła katolickiego w tym czasie była bardzo trudna, ponieważ władze państwowe zlikwidowały kościelne struktury administracyjne oraz utrudniały pracę duszpasterską nielicznym księżom, którzy zostali na terenie Podola. Dopiero upadek ZSRR umożliwił reaktywowanie diecezji kamieniecko-podolskiej przez papież Jana Pawła II w dniu 16 stycznia 1991 roku. Ordynariuszem został ks. Jan Olszański ${ }^{49}$, który pracował na terenie diecezji od 1944 roku

Gródek (Podolski) to miasteczko nad rzeką Smotrycz, w północnej części rejonu kamienieckiego, liczący aktualnie około 17.000 mieszkańców ${ }^{50}$. W Gródku Podolskim mieszka do dzisiaj dużo katolików pochodzenia polskiego, którzy w 1944 roku stanowili ponad $80 \%$ ludności miasta ${ }^{51}$.

Po raz pierwszy Gródek Podolski jest wspominany w 1392 roku. Został wtedy nadany przez książąt Koriatowiczów, niejakiemu Bedryszykowi. Przez pewien czas Gródek nosił nazwę Gródek-Bedrechiwski. W ciągu wieków właścicielami Gródka były rody: Wiśniowieckich, Potockich, Czermińskich, Zamojskich, Mniszchów oraz baron Gejsmar. Na początku XVII wieku Zamojscy odbudowali miasto, po zniszczeniu przez Tatarów ${ }^{52}$.

Pierwszy drewniany kościół pw. św. Antoniego w Gródku został spalony przez Tatarów. W 1496 roku została wybudowana nowa świątynia pw. św. Stanisława, która została zniszczona w 1550 roku, również podczas najazdu tatarskiego.

${ }^{48}$ Dzwonkowski, Leksykon duchowieństwa polskiego represjonowanego w ZSRS 1939-1988, Lublin 2003, s. 359-360.

${ }^{49}$ Jan Olszański - ur. 14 I 1919 r. we wsi Hucisko Brodzkie, rejon Brodzki, obwód Tarnopolski, w rodzinie rolniczej Jana i Marii z domu Bojko. Szkołę podstawową ukończył w rodzinnej wsi. Naukę kontynuował w Brodach. W 1928 r. uzyskał maturę i wstąpił do Seminarium Duchownego we Lwowie, będąc równocześnie studentem Uniwersytetu Jana Kazimierza na Wydziale Teologicznym. W dniu 19 IX 1942 r. otrzymał święcenia kapłańskie. Przez dwa lata był wikariuszem w Kaczanówce. W 1944 r. zgłosił się do pracy duszpasterskiej na Podolu i został skierowany do Gródka Podolskiego. Po aresztowaniu duchownych, ksiądz Olszański w roku 1946 r. został jednym kapłanem katolickim na obszarze całego Podola. Po dwuletniej pracy w Gródku, został zmuszony do wyjazdu do Lwowa gdzie pracował wikariusz w parafii Matki Boskiej Śnieżnej. W 1948 r. dostał zgodę na powrót do Gródka Podolskiego. Duszpasterzował w tym miasteczku przez 10 lat. Ponieważ przyczynił się do ożywienia życia religijnego w Gródku, władze państwowe wysłały go na małą wieś Manikowce. nadal jednak dojeżdżał do opuszczonych placówek duszpasterskich. Po odrodzeniu diecezji kamienieckiej otrzymał sakrę biskupią we Lwowie 16 I 1991 r. Uroczysty ingres do katedry kamienieckiej pw. śś. Apostołów Piotra i Pawła odbył się 8 IV 1991 r. W 2002 r. złożył rezygnację z biskupstwa. Zmarł 23 II 2003 r. w Kamieńcu Podolskim. Oprac. na podstawie: Dzwonkowski, Leksykon duchowieństwa Polskiego, s. 451-452.

${ }^{50}$ С. Гуменюк, Хто ти є?..(Kim ty jesteś?...), Хмельницький 2002, s. 5.

${ }^{51}$ Leksykon duchowieństwa Polskiego, s. 451.

${ }^{52}$ Гуменюк, Хmо ти є?..(Kim ty jesteś?..), s. 6. 
W 1580 roku kościół został odbudowany i powiększony. W roku 1778 przybyli do Gródka franciszkanie z Kamieńca Podolskiego. W miasteczku osiadły również Siostry Miłosierdzia (szarytki). Zgromadzenia te wspomagali m.in. wojewoda podolski Jan Jakub Zamojski i podkomorzy latyczowski Piotr Orłowski. Chojnie uposażyli oni wspomniane placówki zakonne. Franciszkanie sprowadzili ze sobą słynący łaskami obraz św. Antoniego z Padwy. Od tego czasu św. Antoni w swoim obrazie jest patronem i opiekunem Gródka Podolskiego. Do dziś dnia wierni mówią o nim: św. Antoni „Gródecki”. W 1778 roku w Gródku został wybudowany nowy murowany kościół, do którego przeniesiono cudowny obraz św. Antoniego ${ }^{53}$. Świątynia została wysadzona w powietrze w 1937 roku przez władze sowieckie. Od tego czasu wierni zaczęli gromadzić się na modlitwę w kaplicy cmentarnej.

W 1937 roku oprócz zniszczenia kościoła, podczas jednej nocy uwięziono około tysiąca osób w Gródku. Aresztowano Polaków, którzy stanowili miejscową elitą intelektualną i społeczną. Bolszewickie władze zesłały aresztowanych do Kazachstanu, z którego powrócili tylko nieliczni. Również kaplica na cmentarzu została zamknięta. Władze chcąc zastraszyć wiernych ogłosiły, że osoby napotkane przy kaplicy zostaną aresztowane i również wywiezione.

Podczas II wojny światowej, po wkroczeniu do Gródka oddziałów Wermachtu, na prośbę miejscowej ludności, władze wojskowe zgodziły się na otwarcie kaplicy. Do miasteczka zaczęli przyjeżdżać księża zza Zbrucza. Wierni po tak długim czasie nieobecności kapłana, byli bardzo spragnieni mszy św. i sakramentów ${ }^{54}$. W listopadzie 1944 roku w parafii rozpoczął pracę duszpasterską ks. Jan Olszański, który od roku 1946 był jedynym duchownym pracującym na terenie diecezji. Jednak po dwóch latach został on usunięty z Gródka Podolskiego. W 1948 roku udało się mu ponownie przyjechać do miasteczka. Prowadził duszpasterstwo aż do 1958 roku, kiedy to ponownie został usunięty przez władze ${ }^{55}$. Po jego wyjeździe parafia była obsługiwana przez ks. Bronisława Mireckiego i ks. Antoniego Gładysiewicza. Oficjalnie proboszczem był nadal ks. J. Olszański, który przebywał wówczas w Mańkowcach. Jedynie ze specjalnym urzędowym pozwoleniem, mógł dwa razy w roku przybyć do swojej dotychczasowej parafii.

Parafia w Gródku Podolskim pozostawała bez duszpasterza przez 12 lat, aż do roku 1970, kiedy to po długim okresie składania pism i petycji przez wiernych, urzędnicy pozwolili przyjechać ks. Franciszkowi Karasiewiczowi. Otrzymał on zaświadczenie upoważniające go do pracy duszpasterskiej w Gródku datowane na dzień 7 kwietnia 1970 roku. Duchowny stale jednak znajdował się pod czujnym okiem KGB. Na każdej mszy zawsze był obecny ktoś z KGB, analizowane były wypowiedzi księdza, jego kazania, konferencje rekolekcyjne itp. Władze starały się również zastraszyć ks. Karasiewicza i zniechęcić go do aktywnej pracy duszpasterskiej ${ }^{56}$. Mimo szykan, ksiądz odnosił duże sukcesy duszpasterskie,

${ }^{53}$ M. Koprowski, Kresy we krwi, Warszawa 2011, s. 27-28.

${ }^{54}$ Tamże, s. 34.

${ }^{55}$ Dzwonkowski, Leksykon duchowieństwa Polskiego, s. 451

${ }^{56}$ Ф. Карасєвіч, Спогади про душпастерську праию, „Studia Catholica Podoliae”, 6 (2012) s. 435 . 
o czym świadczy liczba wiernych, którzy w 1973 roku wyspowiadali sie przed Świętami Wielkanocnymi: bylo to 4316 osób. Trudne warunki pracy oraz dręczenie psychiczne przez urzędników, spowodowały u ks. Karasiewicza kłopoty ze zdrowiem, wymagające leczenia szpitalnego. $Z$ tego względu nie mógł dalej pełnić swojej posługi. W 1975 roku przeprowadził się do Derażni, gdzie praca duszpasterska nie wymagała aż tak dużego poświęcenia ${ }^{57}$.

Po odejściu ks. Franciszka, przez dwa lata wierni prosili o skierowanie do Gródka nowego kapłana. W tym celu kilka razy odwiedzali biskupa w Rydze. Swoje prośby i pisma kierowali także do urzędów państwowych z prośbą o zezwolenie na obsadzenie parafii. Ogromna determinacja wiernych oraz ich upór przyniosły pozytywne rezultaty. W 1977 roku władze zatwierdziły przyjazd do Gródka kolejnego duchownego. Przez cały ten czas w oczekiwaniu na przybycie nowego duszpasterza, wierni gromadzili się na modlitwę w kaplicy znajdującej się na cmentarzu ${ }^{58}$.

Ks. Wanags przybył do Gródka w Środę Popielcową 23 lutego 1977 roku. Był to również dzień święta Armii Sowieckiej, który zawsze hucznie obchodzono. Jak wspominał Bronisław Szafrański, kiedy po raz pierwszy ks. Władysław szedł do kaplicy, nie mógł przedostać się do niej przez błoto i zmuszony był skakać po kamieniach. Gdy w końcu dotarł na miejsce, powiedział do stojącym przed kaplicą ludziom, że potrzeba zbudować drogę. Wierni odpowiedzieli, że już nie jeden o tym wspominał. Według relacji B. Szafrańskiego, ks. W. Wanags zastał modlących się wiernych w kaplicy. Stanął przy wejściu. Był wysokim, dobrze zbudowanym mężczyzną. Rozglądał się z zaciekawieniem po kaplicy i ludziach, czekając, aż skończą się modlić. Na początku nikt nie wiedział, że był to nowy duszpasterz. Dopiero na drugi dzień rano, kiedy ks. Władysław wyszedł odprawiać mszę św., wierni rozpoznali w nim nieznajomego mężczyznę, którego widzieli poprzedniego dnia $^{59}$.

Na początku parafianie odnosili się do ks. Wanagsa wrogo, ponieważ dowiedzieli się, że był kiedyś wojskowym. Tym bardziej, że zaczął on zarządzać parafią jak jednostką wojskową: wydawał rozkazy, które inni mieli wykonać. Wierni zastanawiali się czy ks. Władysław nie jest agentem KGB, którego celowo przysłano do Gródka, aby władze oficjalnie mogły wydalić ks. Jana Olszańskiego. Podejrzenia te szybko się rozwiały, gdy parafianie zobaczyli z jak wielkim poświęceniem pracuje ks. Wanags. Już po miesiącu jego pobytu w Gródku miało miejsce zdarzenie, o którym do dziś dnia wspominają Michał Jasiński ${ }^{60}$ oraz ks. Alik Swidec ${ }^{61}$. W Wielką Sobotę, tuż przed Wigilią Paschalną, ks. Wanags przygotowany już w kaplicy do odprawiania mszy św., usłyszał głośne krzyki. Wy-

${ }^{57}$ Koprowski, Kresy, s. 47.

${ }^{58}$ Tamże, s. 48.

${ }^{59}$ Wywiad z Bronisławem Szafrańskim, z dnia 26 II 2016 r., w Gródku Podolskim, w zbiorach autorki.

${ }^{60}$ Michał Jasiński - należy do parafii w Gródku Podolskim, był ministrantem ks. W. Wanagsa, pomagał w budowie kościoła. Towarzyszył ks. Wanagsowi, gdy ten udawał się do miasta; chodził z nim do chorych i towarzyszył w wyjazdach do innych parafii.

${ }^{61}$ Wywiad z ks. Alik Swidec, z dnia 24 II 2016 r., w miescie Gródek, w zbiorach autorki. 
biegł na dwór i zobaczył, że pali się dach kaplicy. Pomimo obecności wielu ludzi, którzy wyszli z kaplicy, nikt nie gasił pożaru ale wszyscy stali bezczynnie. Jedynie ks. Władysław szybko wszedł po drabinie na płonący dach. Swoim ubraniem zgasił ogien, przy czym dotkliwie poparzył sobie rękę. Okazało się, że na dach kaplicy został rzucony tzw. „koktajl Mołotowa”, czyli butelka z palącą się smołą, którą bardzo trudno ugasić. Po zagaszeniu pożaru, parafianie zrobili opatrunek ks. Władysławowi, który wrócił do kaplicy, aby rozpocząc mszę św. Wierni zgromadzeni w kaplicy płakali, gdy patrzyli na księdza, który mimo wielkiego bólu ręki odprawiał Eucharystię. Po tym zdarzeniu parafianie zrozumieli, że ks. W. Wanags jest prawdziwym kapłanem, a nie szpiegiem sowieckim. Odtąd cieszył się on niekwestionowanym autorytetem wśród wiernych ${ }^{62}$.

Ks. W. Wanags tak wspominał swoją pierwszą mszę św. w Gródku:

Zwykle kapłani na nowej parafii odprawiają w białym ornacie ze śpiewem chóru, organami, a ja w ornacie fioletowym, pokutnym i z posypaniem głów popiołem. Nikogo nie znałem. Sam z Jezusem i Maryją, lecz bez domu i bez kościoła. Jakże to boleśnie przeżywałem! Siłę dawała mi wiedza, że to Bóg przysłał mnie na Ukrainę oraz wyznaje, że Opatrzność Boża strzegła mnie i lud swój ${ }^{63}$.

W Gródku Podolskim ks. Władysław zamieszkał u rodziny Kosteckich. Ich dom znajdował się niedaleko kaplicy cmentarnej, która była jedynym ośrodkiem religijnym w Gródku. W latach 70. XX wieku kaplica miała wymiary: 7,5 metrów długości, 5,5 metrów szerokości i 3,5 metra wysokości. Ściany były murowane z kamienia. Jeszcze za ks. F. Karasiewicza cmentarna kaplica była przebudowana: podwyższono sufit, dzięki czemu wysokość kaplicy powiększyła się o dwa metry i można było urządzić na górze chór ${ }^{64}$.

W pierwszym roku posługi w Gródku, ks. Wanags rozpoczął prace restauracyjne kaplicy. Władze lokalne nie pozwalały jednak na zrobienie nawet małego remontu, pomalowania ścian czy odnowienia podłogi. Wszystko trzeba było robić potajemnie w nocy. Wielkim pragnieniem ks. Władysława było powiększenie kaplicy, żeby mogła pomieścić wszystkich parafian, gdyż nieraz stali na zewnątrz $\mathrm{w}$ deszczu i mrozie. Plany te wydawały się parafianom nierealnie, gdyż z doświadczenia wiedzieli, że władze nie zgodzą się na żadne prace budowlane w kaplicy. Jednak ks. Wanags bez wahania przystąpił do realizacji zamierzeń, wierząc że dla Boga nie ma nic niemożliwego.

Po złożeniu przez ks. Wanagsa w urzędzie w Gródku wniosku o rozbudowę kaplicy cmentarnej, została powołana komisja z udziałem władz państwowych. Ksiądz został oskarżony przez tę komisję o nieposłuszeństwo rządowi sowieckiemu, a także o to, że nie jest upoważniony do podejmowania takich inicjatyw. Na to kapłan odparł: „Tak chcę i oto bardzo proszę władzę, aby pozwoliła mi na małą rozbudowę: pięć metrów z przodu, pięć metrów z tyłu, pięć metrów z lewej strony i pięć metrów z prawej, ponieważ ludzie marzną i mokną

\footnotetext{
${ }^{62}$ Tamże.

${ }^{63}$ Cyt. za: Kurlandzki, Danilecka, Panie, do kogoż, s. 225.

${ }^{64}$ Wywiad z Michałem Jasińskim, z dnia 26 II 2016 r. w Gródku Podolskim, w zbiorach autorki.
} 
na dworze.” „Za dużo, a dlaczego po pięć metrów?”. „Jak to, ty nie wiesz, że u Pana Jezusa było pięć ran?”. Po takiej odpowiedzi księdza, członkowie komisji zbulwersowani krzyczeli: „Wygonić go z Gródka i nie pozwolić budować pięciu ran!" ${ }^{\prime 65}$.

Lokalne władze starały się zablokować rozbudowę kaplicy. Aparat partyjny posuwał się do szykan oraz sabotażu. Aby ograniczyć dojazd i uniemożliwić budowę, postawiony został znak zabraniający wjazdu na drogę prowadzącą do kaplicy. Jednak władze były bezsilne wobec determinacji kapłana i wiernych ${ }^{66}$.

Nie mając zezwolenia na budowę ks. Wanags postanowił rozpocząc prace remontowe potajemnie. W urzędzie miejskim zgłosił remont podłogi w kaplicy. Jednak zamierzał wykopać pod kaplicą piwnice. Prace odbywały się tylko w nocy. Ludzie wynosili ziemię spod kaplicy i wysypywali na mogiły, żeby nie było śladu robót. Dzięki temu udało się wybudować podziemne pomieszczenie pod kaplicą. Jego ściany zostały obite drewnem, a cisza pozwalała na większe skupienie na modlitwie, jak wspominali m.in. Bronisław Bieliński ${ }^{67}$ oraz ks. Alik Swidec.

Pewnego dnia we latach 80. XX wieku, w radio ogłoszono, że na Ukrainie w województwie chmielnickim, w Gródku Podolskim ludzie modlą się w katakumbach. Informacja ta $\mathrm{w}$ negatywnym świetle przedstawiała sytuację wyznaniową w ZSRR, kiedy oficjalnie władze sowieckie głosiły wobec zagranicy wolność religijną. Dla zniwelowania negatywnego wydźwięku tej informacji, władze państwowe pozwoliły na budowę kościoła w Gródku. Rząd wydelegował nawet swojego architekta, który miał zaprojektować kościół. Ten jednak nie potrafił tego zrobić, gdyż nigdy nie projektował kościoła. Według jego szkicu świątynia miała wyglądać jak wielka sala gimnastyczna. Pomimo pomocy ze strony ks. Wanagsa, który dał mu stare książki z przedstawieniami polskich kościołów, architekt nie potrafił wywiązać się z powierzonego mu zadania. W związku z tym ks. Władysław pojechał do Rygi i znalazł tam architekta, który zaprojektował kościół. $\mathrm{Z}$ gotowym planem ks. Wanags wrócił do Gródka i potajemnie oddał go w ręce upoważnionego przez władzę architekta. Urzędnikom projekt się nie spodobał, ponieważ świątynia miała być według nich zbyt wysoka. Usunęli oni górną część kościoła na projekcie, żeby nie było widać świątyni zza drzew i dopiero wtedy zatwierdzili projekt. Władze planowały, że wprawdzie pozwolą na budowę, ale nie wydadzą zgody na dostarczenie materiałów i w ten sposób kościół nie zostanie wzniesiony. Ponieważ pozwolenie było potrzebne nawet na przywiezienie piachu czy kamienia, parafianie wypisywali materiały budowlane dla swoich potrzeb. Trzymali je na swoich podwórkach, a kiedy były potrzebne, w nocy przywozili pod kościół. Dzięki ogromnej ofiarności i determinacji parafian udało się wybudować tę świątynię. Przy jej wznoszeniu pracowały osoby starsze, kobiety, a nawet dzieci $^{68}$.

${ }^{65}$ Cyt. za: Kurlandzki, Danilecka, Panie, do kogoż, s. 227.

${ }^{66}$ Wywiad z ks. Alik Swidec, z dnia 24 II 2016 r., miasto Gródek; w zbiorach autorki.

${ }^{67}$ Bronisław Bieliński - parafianin z Gródka. Znał ks. Władysława Wanagsa od pierwszego dnia jego przyjścia do parafii. Przez jakiś czas był jego kierowcą.

${ }^{68}$ Wywiad z ks. Alik Swidec, z dnia 24 II 2016 r., miasto Gródek; w zbiorach autorki. 
Budowa świątyni zaczęła się w 1983 roku. Pierwszą część kościoła wzniesiono w ciągu dwóch i pół miesiąca. Wierni pracowali na dwie zmiany. Wszystkie podania i prośby wiernych dotyczące prac budowlanych, były przez władze załatwiane odmownie. W ten sposób chciano wstrzymać budowę kościoła ${ }^{69}$.

Ponieważ ks. Wanagsowi udało się jednak wybudować kościół mimo wielu utrudnień ze strony władz, KGB zaczęło go szykanować aż do 1988 roku. Rejestrowano jego kazania, aby znaleźć coś kontrowersyjnego, śledzono każdy krok kapłana, podburzano ludzi przeciwko niemu. Organizowano specjalne spotkania na których starano się zdyskredytować osobę ks. Wanagsa. Władze naciskały na biskupa ryskiego by przeniósł marianina na inną placówkę ${ }^{70}$. Posuwano się do prób fizycznej eliminacji nieugiętego pasterza. Samochód ks. Wanagsa został najechany przez ciężarówkę. Jednak kapłana wówczas nie było w aucie. Ofiarą stał się inny ksiądz, który jechał wtedy samochodem; „,wypadek” zakończył się połamaniem przez niego żeber. Kilkukrotnie próbowano także zmusić ks. Władysława do współpracy z KGB. Nigdy jednak nie wyraził na nią zgody, a pomimo to dalej pracował w Gródku. Gdy szedł do urzędu, witał się słowami: „Mir wam” a urzędnikom wręczał obrazki świętych ${ }^{71}$.

Jak wspomina ks. Jan Bilecki, ks. W. Wanags nigdy się nie bał. Gdziekolwiek szedł, mówił, że idzie z Bogiem więc nic się mu nie stanie. Był pewien tego co robi, gdyż wszystko czynił na chwałę Bożą. Trzymał się zawsze jednej zasady, a była nią wiara. A gdy ktoś wątpił i bał się, to ks. Wanags mawiał: „słabą wiarę masz"72.

Życiowym credo ks. Wanagsa były dwa słowa: „mir wam ${ }^{73}$ ”, które wymawiał zawsze z ogromną wiarą. Przedstawiciele władzy często nie wiedzieli jak odpowiedzieć na to pozdrowienie, co powodowało ich uległość wobec próśb marianina. Ks. Władysław był częstym „gościem” lokalnych urzędów. Po którejś z „wizyt" próbowano go nawet pobić. Jednak ks. Wanags jako były wojskowy, poradził sobie bez problemu z napastnikami. Po pewnym czasie, gdy spotkał swoich prześladowców, powiedział do nich: „Kocham was i pragnę dużo zrobić dla waszego zbawienia. Jesteśmy braćmi, lecz stoi na przeszkodzie między nami diabeł - to on jest wrogiem". Nigdy ks. Wanags nie obrażał się na swoich prześladowców i traktował ich, jako swoich przyjaciół.

Ponieważ od wybudowania pierwszej części kościoła minęło pięć lat, wierni na czele z ks. Wanagsem bezskutecznie pisali prośby i wnioski do urzędów o pozwolenie na budowę drugiej części kościoła. W związku z tym ks. Wanags zrozumiał, że nie dostaną pozwolenia i postanowił rozpocząć prace bez urzędowego zezwolenia $^{74}$. Oczywiście $\mathrm{w}$ momencie rozpoczęcia robót budowlanych przybyli $\mathrm{z}$ miasta funkcjonariusze z zarzutem o nielegalnej budowie. Ks. Władysław po-

${ }^{69}$ Szpyczko, Rożkow, Ojciec Władystaw Wanags MIC, s. 262.

${ }^{70}$ Wywiad z Michałem Jasińskim, z dnia 26 II 2016 r. w Gródku Podolskim; w zbiorach autorki.

${ }^{71}$ Kurlandzki. Danilecka, Panie, do kogoż, s. 226.

${ }^{72}$ Wywiad z ks. Janem Bileckim w dniu 13 X 2016 r., na wsi Demiankowce; w zbiorach autorki.

${ }^{73}$ „Mir wam” (j. rosyjski) - ,pokój wam”.

${ }^{74}$ Wywiad z Bronisławem Szafrańskim, dnia 24 II 2016 r. w Gródku Podolskim; w zbiorach autorki. 
wiedział wówczas: „Złożyłem już wniosek, ale żadnej odpowiedzi nie ma. Zrozumiałem, że milczenie jest zgodą". Po tej odpowiedzi zaprosili księdza jeszcze raz do urzędu i dopiero wtedy wydano pozwolenie na budowę ${ }^{75}$. W 1988 roku, w ciągu 9 miesięcy powstał duży kościół, pw. Matki Bożej Wniebowziętej i św. Stanisława Biskupa ${ }^{76}$.

Po zakończeniu prac budowlanych, kościół został konsekrowany w dniu 17 września 1988 roku przez bpa ryskiego Niuksza, którego osobiście poprosił o to ks. Władysław. Marianin spłacił w ten sposób dług wdzięczności swojemu ordynariuszowi, za posłanie go do pracy duszpasterskiej w Gródku Podolskim ${ }^{77}$. Na uroczystość konsekracji kościoła przyjechało dużo wiernych z diecezji kamienieckiej. W uroczystości uczestniczyli licznie duchowni z diecezji oraz księża z zagranicy. Cały teren wokół kościoła oraz cmentarz były wypełnione ludźmi. We wspomnieniach parafian dzień ten pozostał szczególnie radosnym momentem ich życia, a jego rocznica jest obchodzona w każdej rodzinie katolickiej jako wielkie święto ${ }^{78}$.

Drugim wielkim dziełem ks. Wanagsa w Gródku był Dom Miłosierdzia. Miało być to schronisko przy kościele, dla najbiedniejszych i opuszczonych ludzi. Środków do realizacji tego projektu kapłan szukał za granicą. Pojechał w tym celu do Stanów Zjednoczonych, gdzie mieszkał jego brat oraz do Austrii. Głównym jednak celem jego podróży w poszukiwaniu potrzebnych środków do budowy była Polska. Miał tam dużo znajomych duchownych oraz osób świeckich. Tak wspomina okoliczności jednego z wyjazdów księdza Władysława Bronisław Szafrański:

Jednego razu ks. Wanagsa okradli w drodze do domu. Były to pieniądze na dalszą budowę schroniska dla ubogich. Ojciec Władysław wrócił bardzo smutny i od razu poszedł się modlić przed obrazem św. Antoniego w kościele, którego kiedyś obrał za orędownika swych spraw. Gorąco prosił świętego o pomoc, ponieważ następnego dnia mieli przyjść robotnicy i trzeba było im zapłacić. Spędził na modlitwie w kościele całą noc. Świtem, kiedy poszedł do zakrystii przygotowywać się do porannej mszy, przyszła do zakrystii niewiadoma kobieta i przyniosła w ofierze na budowę domu dla ubogich dużą kwotę pieniędzy ${ }^{79}$.

Po wielu trudnościach związanych z budową, schronisko dla ubogich zostało oddane do użytku w 1998 roku jako „Dom Miłosierdzia”.

Dom dla biednych i ubogich zmienił swe przeznaczenie w 1991 roku wraz z odnowieniem struktur diecezji kamienieckiej (kamieniecko-podolskiej). Ponieważ bp J. Olszański bezskutecznie domagał się od władz zwrotu gmachu seminaryjnego w Kamieńcu Podolskim, ks. Wanags oddał budynek Domu Miłosierdzia

${ }^{75}$ Kurlandzki, Danilecka, Panie, do kogoż, s. 228.

${ }^{76}$ Rota, Kościoły i sanktuaria. Ksiadz Władystaw Wanags, s. 61.

${ }^{77}$ Szpyczko, Rożkow, Ojciec Władysław Wanags MIC, s. 263.

${ }^{78}$ Wywiad z Michałem Jasińskim, z dnia 26 II 2016 r. w Gródku Podolskim; w zbiorach autorki.

${ }^{79}$ Wywiad z Bronisławm Szafrańskim, z dnia 24 II 2016 r. w Gródku Podolskim; w zbiorach autorki. 
w Gródku na potrzeby odradzającej się diecezji. We wrześniu 1991 roku zostało erygowane tu Wyższe Seminarium Duchowne Diecezji Kamieniecko-Podolskiej ${ }^{80}$.

Myśląc o potrzebach duchowych wiernych gródeckiej parafii ks. W. Wanags wybudował jeszcze w latach 1995-1998 dwa kościoły filialne w: Marchliwce i Stancji Wiktoria.

\section{Zaangażowanie księdza w budowę i odnawianie świątyń}

Ks. Wanags zasłynął jako wielki budowniczy. Dzięki jego straniom wiele światyń znajdujących się w okolicach Gródka zostało odnowionych lub zbudowannych od podstaw.

Oprócz parafii w Gródku, ks. Wanags miał pod opieką jeszcze kilka innych: Andrzejowce, oraz Satanow w rejonie czemirowieckim. Tarnoruda, Wołoczysk, Zawalijk w rejonie wołoczyskim oraz Tynnę w rejonie dunajowieckim ${ }^{81}$. Prawie w każdej z nich zbudował kościół. Łącznie w miejscowościach położonych niedaleko Gródka Podolskiego, dzięki staraniom ks. Wanagsa zbudowano 20 świątyń, a 9 wyremontowano ${ }^{82}$. Do tej pory świątynie wzniesione przez niego odznaczają się swoistym stylem architektonicznym, nawiązującym do gotyku i baroku. Często świątynie te mają wysokie smukłe wieże, nieodłącznym elementem ozdobnym każdej świątyni jest oko „Opatrzności”, spoglądające na wiernych z frontonu kościoła. Duchowni opiekujący się tymi obiektami żartobliwie nazywają je $w a-$ nagsstrojkami ${ }^{83}$.

Pierwszą odzyskaną od władz i odbudowaną przez ks. Wanagsa świątynią był kościół w Tarnorudzie, w rejonie wołoczyskim ${ }^{84}$. Jest to wieś położona $65 \mathrm{~km}$ na zachód od Gródka. Tamtejsza ludność była przeważnie narodowości polskiej, wyznania rzymskokatolickiego ${ }^{85}$. Dzisiejszy kościół został zbudowany przez rodzinę Sieniawskich w 1643 roku, a w 1754 roku odrestaurowany przez księcia Czartoryskiego. Miał bogaty wystrój wnętrza. Kościół tarnorudzki słynął na Podolu jako sanktuarium. Znajdował się tam obraz Jezusa Chrystusa Nazareńskiego - Miłosiernego. Na odpust 16 lipca licznie przybywali do sanktuarium pielgrzymi z całego kraju ${ }^{86}$. W 1920 roku ówczesny proboszcz, obawiając się o los wspomnianego wizerunku, wywiózł go do Tarnopola. Gdy ks. Wanags odzyskał świątynię wymagała ona remontu, ponieważ stan zabytkowego obiektu był katastrofalny. Na budowli rosły drzewa i chwasty, nie było dachu, tylko gołe ściany. Ksiądz

${ }^{80}$ Kurlandzki, Danilecka, Panie, do kogoż, s.228-229.

${ }^{81}$ Szpyczko, Rożkow, Ojciec Władystaw Wanags MIC, s. 263.

${ }^{82}$ Kościoły i sanktuaria. Ksiadz Władysław, s. 62.

${ }^{83}$ Jak ksiądz Wanags kościoly budowat, http://www.kresy.pl/publicystyka,reportaze?zobacz/ jak-ksiadz-wanags-koscioly-budowal (dostęp: 9.03.2016)

${ }^{84}$ Wywiad z Michałem Jasińskim, z dnia 26 II 2016 r. w Gródku Podolskim; w zbiorach autorki.

${ }^{85}$ Kościoly i sanktuaria. Ksiądz Władystaw, s. 62.

${ }^{86}$ Схематизм. Камянеиь-подільська дієиезія під захистом Пресвятого Серия Господа Icyca, [Kamieniec Podolski 2001] s. 206; Tarnoruda, w: Stownik Geograficzny Królestwa Polskiego i innych krajów stowiańskich, t. 12, red. B. Chlebowski, Warszawa 1892, s. 195. 
nie tylko odbudował kościól, ale zbudował też plebanię. Specjalnie dla parafii w Tarnorudzie przywiózł dzwony z Polski ${ }^{87}$.

Kolejnym miejscem kultu odzyskanym dla wiernych była świątynia w miejscowości Tynna, która znajduje się $38 \mathrm{~km}$ na północ od Gródka. Pierwszy drewniany kościół pw. św. Wojciecha wzniesiono tu w 1597 roku, jednak został zniszczony przez Turków. W roku 1717 został wzniesiony nowy murowany kościół, który w latach: 1894 i 1904 poddano renowacjom. W czasie władzy sowieckiej świątynia została zburzona, a na jej miejscu zbudowano szkołę. Dopiero w 1990 roku ks. Władysław Wanags rozpoczął budowę kościoła na zamkniętym cmenta$\mathrm{rzu}^{88}$. Nowy budynek kościoła może pomieścić ponad 1500 osób $^{89}$.

Sołobkowce to wieś znajdująca się w pobliżu Tynny, oddalona od Gródka 46 km. Murowany kościół pochodzący z 1650 roku, został w latach trzydziestych $\mathrm{XX}$ wieku zniszczony. Wierni z miejscowości zwrócili się do ks. Wanagsa z prośbą o pomoc w odbudowie świątyni. Najpierw wzniesiono prowizoryczną kaplicę. $\mathrm{Na}$ fundamentach zniszczonego w latach trzydziestych kościoła postawiono mury nowego, stylistyką zbliżonego do świątyni w Tynnie ${ }^{90}$. Ks. Wanagsowi udało się zebrać prawie 15 ton złomu miedzianego, za który w Polsce, w ludwisarni Felczyńskich otrzymał dzwony, które miały zawisnąć na wieży kościoła w Sołobkowcach. Na granicy celnicy nie chcieli jednak zezwolić na wwiezienie dzwonów na Ukrainę, argumentując to potrzebą posiadania stosownego zezwolenia ze Lwowa. Ostatecznie po licznych prośbach, duchowny otrzymał pozwolenie na przewiezienie dzwonów przez granicę ${ }^{91}$.

W 1992 roku z prośbą o wzniesienie kościoła zwrócili się do ks. Władysława mieszkańcy wsi Łużkowce, położonej w odległości $6 \mathrm{~km}$ od Sołobkowiec. Swą prośbę motywowali znaczną odległością do kościoła w Sołobkowcach oraz podeszłym wiekiem większości wiernych. Parafianom udało się z pomocą krewnych mieszkających za granicą, zdobyć odpowiednie środki. Kupiono za nie materiały budowlane oraz opłacono architekta, który sporządził plany kościoła. Wierni zapewnili utrzymanie pracownikom budującym świątynię. Po dwóch latach budowy, bp J. Olszański w 1994 roku poświęcił kościół i niewielką plebanię ${ }^{92}$.

Parafia Żyszczyńce znajduje się $6 \mathrm{~km}$ od Gródka i zamieszkana jest przez Polaków. Z powodu braku własnej świątyni, wierni musieli jeździć do Gródka ${ }^{93}$. W 1992 roku dzięki zaangażowaniu ks. Wanagsa i mieszkańców wioski, rozpoczęto budowę świątyni. Kościół został zbudowany w ciągu czterech lat, a poświęcony został w 1997 roku przez bpa J. Olszańskiego ${ }^{94}$.

\footnotetext{
${ }^{87}$ Kościoly i sanktuaria. Ksiąz Władysław, s. 62.

${ }^{88}$ Схематизм. Камянеиь-подільська дієцезія, s. 123.

${ }^{89}$ Kościoły i sanktuaria. Ksiądz Władystaw, s. 62.

${ }^{90}$ Схематизм. Камянець-подільська дієцезія, s. 87.

${ }^{91}$ Kurlandzki, Danilecka, Panie do kogóż, s.232-233.

${ }^{92}$ Схематизм. Камянець-подільська дієиезія, s. 110; Kurlandzki, Danilecka, Panie do kogóż,

${ }^{93}$ Kościoly i sanktuaria. Ksiadz Władysław, s. 62.

${ }^{94}$ Схематизм. Камянець-подільська дієиезія, s. 78.
} s 233. 
Po ukończeniu prac w Żyszczyńce, ks. Wanags rozpoczął prace przy świątyni w miejscowości Mudrygłowy, oddalonej od Gródka o $9 \mathrm{~km}$. Prace budowlane trwały w latach 1992-1996. Konsekracji kościoła dokonał bp J. Olszański. Parafia w Mudrygłowach otrzymała wezwanie św. Franciszka ${ }^{95}$.

We wsi Petrykowce, odległej o $9 \mathrm{~km}$ od Gródka, dla potrzeb kultu chciano zaadaptować budynek starego sklepu. Ponieważ mieszkający we wsi prawosławni protestowali przeciw temu, ks. Władysław wybudował neogotycki kościół z dwoma wieżami i plebanią. Później ks. Wanags z lekką ironią dziękował prawosławny, że w skutek ich sprzeciwowi w Petrykowcach powstała piękna katolicka świątynia ${ }^{96}$.

Satanow znajduje się $34 \mathrm{~km}$ od Gródka. Mieszkający tam ludzie przeważnie są narodowości polskiej. Kościół znajdujący się w centrum miasteczka, został wysadzony w powietrze po II wojnie światowej. W 1990 roku ks. W. Wanags rozpoczął budowę kościoła. W ciągu czterech lat powstał kościół pw. Najświętszej Marii Panny. Parafię w Satanowie bp J. Olszański powierzył sprowadzonym z Polski paulinom ${ }^{97}$.

Parafia Wołoczysk to miasto dwa razy większe od Gródka, w odległości 70 $\mathrm{km}$ od niego. Początkowo rozpoczęto remont starego kościoła, przerobionego $\mathrm{w}$ czasach sowieckich na fabrykę. Jednak koszty przebudowy i remontu były bardzo duże. Dlatego też w maju 1992 roku ks. Wanags rozpoczął budowę kościoła, którą zakończono ostatecznie w trzy lata później. W dniu 8 grudnia 1995 roku bp J. Olszański poświęcił kościół pw. Niepokalanego Poczęcia Najświętszej Panny Marii ${ }^{8}$. W parafii dzięki staraniom ks. Władysława funkcjonują dwa kościoły rzymskokatolickie: nowy i wyremontowany stary ${ }^{99}$.

W 1996 roku ks. Władysław wybudował kościół pw. św. Andrzeja Apostoła w Sachkamieniu. Biskup J. Olszański 30 listopada tegoż roku poświęcił świątynię. Obok kościoła został wzniesiony dwupiętrowy dom z przeznaczeniem na przyszły nowicjat. Po konsekracji został oddany Zgromadzeniu Pasjonistów, mieszkających w Smotryczu ${ }^{100}$.

Ks. Wanags wzniósł także kościół w Czemerowcach koło Satanowa. Budowa świątyni w miejscowości była sabotowana przez władzę, protestowali także prawosławni. Sytuacja była podobna do tej która, towarzyszyła budowie kościoła w Petrykowcach. Jednak mieszkający w mieście katolicy byli zdeterminowani, aby wznieść własną świątynię. Argumentem przemawiającym za budową była odległość $8 \mathrm{~km}$ jaką do kościoła w Smotryczu musieli każdorazowo pokonać ludzie udający się na msze św. Władze początkowo nie zgadzały się na budowę świątyni w centrum miasta. Ostatecznie po licznych pertraktacjach katolicy uzy-

${ }^{95}$ Kościoły i sanktuaria. Ksiądz Władysław, s. 62; Kurlandzki, Danilecka, Panie do kogóż pójdziemy?, s. 235.

${ }^{96}$ Kościoły i sanktuaria. Ksiądz Władystaw, s. 62; Kurlandzki, Danilecka, Panie do kogóż pójdziemy?, s. 235-236.

${ }^{97}$ Схематизм. Камянеиь-подільська дієиезія, s 86.

${ }_{98}$ Tamże, s. 185.

${ }^{99}$ Szpyczko, Rożkow, Ojciec Władystaw Wanags MIC, s. 265.

${ }^{100}$ Схематизм. Камянеиь-подільська дієцезія, s. 117. 
skali zgodę na budowę kościoła na obrzeżach miasta. W zdobyciu niezbędnych do budowy kościoła środków pomógł ks. Wanagsowi ks. prof. Stanisław Siwiec. Budowla wzniesiona w latach 1996-1998, jest dedykowana Matce Bożej Częstochowskiej ${ }^{101}$.

Dziełem przedsiębiorczego kapłana był także niewielki kościółek we wsi Andrzejówka. W miejscowości Nowa Uszyca od połowy XIX wieku znajdowała się piękna świątynia. W latach sześćdziesiątych kolejnego stulecia została zniszczony, a na jej miejscu wybudowano szkołę. W 1994 roku ksiądz Wanags rozpoczął budowę nowego kościoła. Wybrał piękne miejsce na wzgórzu w centrum miasta. Powstała duża świątynia z dwoma wieżami, mogąca pomieścić 1000 osób. Obecnie parafią w Nowej Uszycy opiekują się Misjonarze Oblaci ${ }^{102}$.

Na duże trudności napotkał ks. Wanags przy odbudowie kościoła Smotryczu. Świątynia została wzniesiona w 1821 roku Zamknięto ją na rozkaz władz sowieckich w 1935 roku Później w budynku znajdował się klub i sala do nauczania ateistycznego. Kiedyś ks. Wanagsowi udało się wejść do tego klubu i za organami, które znajdowały się w budynku dawnej świątyni, schował małą figurkę Matki Boskiej, wierząc, że pomoże to w odzyskaniu kościoła. Wierni z ks. Władysławem długo walczyli z władzami państwowymi o odzyskanie budynku dawnej świątyni. Pewnego dnia ksiądz zebrał grupę parafian, na których czele wszedł do budynku klubu i zaczął z wiernymi odmawiać różaniec. Od razu wezwano go na rozmowę do urzędu. Przedstawiciele władz widząc determinacje wiernych oraz odwagę ks. Wanagsa polecili oddać klucze do kościoła. W 1989 roku kościół został odnowiony a później konsekrowany. Świątynia w Smotryczu została decyzją biskupa kamienieckiego przekazana Zgromadzeniu Pasjonistów, którzy wznieśli przy niej swój klasztor i nowicjat ${ }^{103}$.

Do kościoła w Smotryczu uczęszczali wierni z miejscowości Smotryczówka, oddalonej od Smotrycza o $7 \mathrm{~km}$. Pragnęli oni posiadać w swojej miejscowości kościół. Udali się więc do ks. Wanagsa, który pomógł im wznieść kościół w przeciągu dwóch lat ${ }^{104}$.

Następnym odbudowanym kościołem przez ks. Władysława była świątynia w Kumanowie, oddalonym o $25 \mathrm{~km}$ od Gródka. Po II wojnie światowej kościół był prawie całkiem zniszczony, zachowała się tylko jedna ściana. W ciągu dwóch lat na miejscu starej świątyni powstał nowy kościół oraz plebania ${ }^{105}$.

W Kuźminie odległym od Gródka o $18 \mathrm{~km}$, władze oddały wiernym budynek starej szkoły, która została wzniesiona w miejscu zburzonego kościoła. Do budynku dobudowano prezbiterium, wieżę, zakrystię oraz mieszkanie dla księdza.

W Kupinie władze oddały katolikom jako rekompensatę za zniszczony kościół, budynek, w którym znajdował się sklep. Przystosowano go do potrzeb wiernych. Kupin znajduje się $15 \mathrm{~km}$ od Gródka. W latach trzydziestych po wywie-

\footnotetext{
${ }^{101}$ Kurlandzki, Danilecka, Panie do kogóż pójdziemy?, s. 239.

${ }^{102}$ Kościoły i sanktuaria. Ksiadz Władysław, s. 62.

${ }^{103}$ Схематизм. Камянеиь-подільська дієиезія, s. 120.

${ }^{104}$ Kościoły i sanktuaria. Ksiądz Władysław, s. 62.

${ }^{105}$ Схематизм. Камянецьь-подільська дієцезія, s. 81-82.
} 
zieniu mieszkających tam Polaków do Kazachstanu i na Syberię, wieś stała się częścią kołchozu.

Ks. Wanagsowi udało się odrestaurować również murowaną świątynię w miejscowości Jasinówka, leżącej 16 km na wschód od Gródka. Kościół znajdował się w tej miejscowości już od 1803 roku Podobnie jak w poprzednich przypadkach, władze państwowe po odebraniu świątyni wiernym, zamieniły kościół na budynek użyteczności publicznej (klub). Budynek zwrócono wiernym w 1989 roku ${ }^{106}$

Jarmolińce to duże miasteczko położone $18 \mathrm{~km}$ na północ od Gródka. W samym centrum miasta znajduje się kościół zamieniony w czasach sowieckich na kino, a później na dom kultury. Na frontonie dawnego kościoła wisiał portret Lenina. Do ks. Wanagsa zgłosiła się grupa wiernych z prośbą o pomoc w odzyskaniu świątyni. Kapłan polecił im zebrać jak najwięcej ludzi pod kościołem, a sam przywiózł do miejscowości duży krzyż i figurę Matki Bożej. Z tymi przedmiotami, na czele wiernych wszedł do świątyni i zaczął śpiewać różaniec. Natychmiast na miejscu pojawili się przedstawiciele władz: prokurator, naczelnik milicji i mer miasteczka. Pertraktacje nie przyniosły skutku. Ponieważ w tym czasie odbywały się wybory do parlamentu, lokalny poseł przyszedł do ks. Wanagsa z prośbą, aby katolicy poparli jego kandydaturę. Ks. Władysław zgodził się, pod warunkiem pomocy w odzyskaniu kościoła. Układ okazał się owocny, gdyż w 1989 roku kościół został zwrócony wiernym. Po remoncie trwającym osiem miesięcy, świątynia została przywrócona do kultu religijnego. Przy kościele ks. Wanags wzniósł także klasztor dla sióstr sercanek ${ }^{107}$.

Nowe świątynie ks. Wanags wybudował także w Podleśnym Oleksiniecu i Balynie. Następny kościół został wybudowany w Borszczowie, miejscowości znajduje się między Gródkiem a Satanowem. W 1991 roku rozpoczęto budowę kościoła, nad którą również czuwał ks. Władysław Wanags. W ciągu dwóch lat powstał tam niewielki kościół pw. Miłosierdzia Bożego ${ }^{108}$.

W Zińkowie świątynia została zniszczona w roku 1938. Po barokowej świątyni pozostały tylko dwie ściany. W 1993 roku na prośbę wiernych, za pozwoleniem biskupa kamienieckiego, ks. Władysław Wanags wybudował na starym fundamencie, nowy kościół pw. Świętej Trójcy. Do świątyni został także sprowadzony dzwon $^{109}$.

W miejscowości Czercz pierwsza świątynia została wzniesiona w 1637 roku. W 1930 roku władze sowieckie zamknęły kościół, który wierni odzyskali dopiero 1993 roku. Ks. Władysław na prośbę wiernych doprowadził do remontu zabytkowej świątyni ${ }^{110}$.

${ }^{106}$ Kurlandzki, Danilecka, Panie do kogóż pójdziemy?, s. 245-247.

${ }^{107}$ Схематизм. Камянецьь-подільська дієиезія, s. 91; Kurlandzki, Danilecka, Panie do kogóż pójdziemy?, s. 246-249.

${ }^{108}$ Схематизм. Камянеиь-подільська дієиезія, s. 73.

${ }^{109}$ Kościoły i sanktuaria. Ksiądz Władysław, s. 62.

${ }^{110}$ Схематизм. Камянець-подільська дієиезія, s. 87-88. 
W Klinowie, wiosce znajdującej się $22 \mathrm{~km}$ od Gródka, ks. Władysław wybudował kościół pw. Matki Bożej Miłosiernej. Jego konsekracja miała miejsce w 1994 roku$^{111}$.

Ostatnią, świątynią odrestaurowaną przez ks. W. Wanagsa, był kościół w Kutkowcach. To niewielka miejscowość położona $20 \mathrm{~km}$ od Gródka Podolskiego. W 1786 roku ukończono budowę kościół. W czasach bolszewickich świątynia została zabrana wiernym i urządzono w niej bibliotekę a później klub. Po 1990 roku świątynię udało się ponownie uczynić miejscem sprawowania kultu ${ }^{112}$. Ks. Władysław, aby przekonać urzędnika do oddania kościoła posunął się do podstępu. Mieszkańcy tych terenów charakteryzowali się wielką wiarą lub jeśli nie byli wierzący - zabobonnością. Ks. Wanags nachodził urzędnika grożąc mu karą Bożą, jeśli nie wyda zezwolenia na zwrot kościoła. Mówił urzędnikowi, że dla dobra własnego i bliskich powinien się zgodzić. W przeciwnym razie, zapowiedział, że będzie się modlił, by za opieszałość spotkała go szybka kara. Urzędnik przestraszył się i wydał zgodę na zwrot kościoła wiernym ${ }^{113}$.

\section{Ostatnie lata życia}

W latach 90. XX wieku, stan zdrowia ks. Wanagsa zaczął się pogarszać. Bez względu na to, kapłan dalej ciężko pracował. Kierował budowami kościołów, załatwiał urzędowe sprawy zwrotu świątyń oraz oczywiście nie zaniedbywał duszpasterstwa. Diagnoza lekarska nie pozostawiała złudzeń: nowotwór. Ks. Wanags często jeździł na leczenie do szpitala wojskowego w Krakowie. Przeszedł kilka operacji oka ${ }^{114}$. Mimo bólu, nigdy nie pokazywał swego cierpienia.

Ks. Władysław Wanags był pierwszym laureatem nagrody Totus Fundacji „Dzieło Nowego Tysiąclecia”, za osiągnięcia w pracy charytatywnej oraz edukacyjno-wychowawczej. Uroczyste wręczenie dyplomu odbyło się na Zamku Królewskim w Warszawie w dniu 28 marca 2001 roku. Okolicznościowy dyplom oraz czek pieniężny wręczył ks. Wanagsowi prymas Polski kard. Józef Glemp, w obecności m.in. nuncjusza abpa Józefa Kowalczyka, bpa Piotra Jareckiego, bpa Jana Cieplaka, premiera Jerzego Buzka, marszałka senatu prof. Alicji Grześkowiak, marszałka sejmu Macieja Płażyńskiego. Otrzymane pieniądze ks. Władysław przeznaczył na potrzeby Domu Miłosierdzia ${ }^{115}$.

Ks. Władysław Wanags zmarł w Gródku Podolskim w dniu 18 listopada 2001 roku, o godzinie 23.25. Tę smutną nowinę obwieściły mieszkańcom bijące dzwony kościoła pw. św. Stanisława Biskupa i Męczennika. Kapłan zmarł w siedemdziesiątym roku życia. W jego pogrzebie uczestniczyło kilka tysięcy ludzi, nie tylko z Podola, ale i innych terenów Ukrainy. Obecni byli kapłani oraz wierni z zagranicy, reprezentanci różnych wyznań i narodowości. Mszę żałobną celebrował ordynariusz diecezji kamienieckiej bp Jan Olszański w asyście sześciu biskupów.

\footnotetext{
${ }^{111}$ Kościoty i sanktuaria. Ksiądz Władysław, s. 62

${ }^{112}$ Схематизм. Камянець-подільська дієцезія, s. 82.

${ }^{113}$ Kurlandzki, Danilecka, Panie do kogóż pójdziemy?, s. 256-257.

${ }^{114}$ Kościoly i sanktuaria. Ksiadz Władystaw, s. 63.

${ }^{115}$ Kurlandzki, Danilecka, Panie, do kogoż, s. 261-262.
} 


\section{Zakończenie}

Antyreligijna polityka państwa sowieckiego stawiała sobie za główny cel likwidację Kościoła, jako głównej przeszkody w realizacji „socjalistycznego raju na ziemi. W tak ciężkich warunkach heroiczny trud posługi duszpasterskiej podejmowali ludzie o niezwykłym charakterze. Jednym z nich był Władysław Wanags, który przeszedł do historii jako „kapłan-budowniczy”. W ciągu 10 lat zdołał wybudować: 20 nowych kościołów, 29 domów parafialnych, dwa gmachy dla seminarium duchownego, dom dla ubogich i starców oraz odrestaurować 9 świątyń. $\mathrm{Z}$ zachowanych relacji i wspomnień udało się odtworzyć koleje losu oraz posługi tego niezwykłego pracownika Winnicy Pańskiej.

Słowa kluczowe: Władysław Wanags; Gródek Podolski; Diecezja Kamieniecko-Podolska; XX wiek; Komunizm; ZSRR; Ukraina

\section{BIBLIOGRAFIA}

\section{Źrodla}

Relacje ustne

Genadiusza Bileckiego ze wsi Słobódka Rachnowiecka, rej. Dunajowiecki, obw. Chmielnicki, Ukraina z dnia 28 XI 2015 r.; w zbiorach autorki.

Bronisława Szafrańskiego, z dnia 24 II 2016 r. i 26 II 2016 r. w Gródku Podolskim; w zbiorach autorki.

Ks. Alik Swidec, z dnia 24 II 2016 r., w Gródku Podolskim; w zbiorach autorki.

Ks. Jana Bileckiego z dniu 13 X 2016 r., we wsi Demiankowce; w zbiorach autorki.

Michała Jasińskiego, dnia 26 II 2016 r., w Gródku Podolskim; w zbiorach autorki.

\section{Opracowania}

Biletska Mariia, Prześladowanie duchowieństwa katolickiego na Podolu w czasach sowieckich na przykładzie ks. Jana Brydyckiego (1864-1937), w: Studia nad polityką polską XX wieku. Relacje państwo - Kościól, red. M. Ryba, Lublin 2016, s. s. 225240.

Dzwonkowski Roman, Kościół katolicki w ZSSR 1917-1939. Zarys historii, Lublin 1997.

Dzwonkowski Roman, Leksykon duchowieństwa polskiego represjonowanego w ZSRS 1939-1988, Lublin 2003.

Dzwonkowski Roman, Od Kościoła polskiego do Kościoła Polaków w krajach byłego ZSSR, „Przegląd Wschodni”, 5 (1998) z. 2, s. 281-297.

Dzwonkowski Roman, Polacy w Kościele katolickim na Wschodzie (1939-2011), Toruń 2011.

Dzwonkowski Roman, Represje władz sowieckich wobec duchowieństwa katolickiego obrządku łacińskiego w latach 1939-1987, „Przegląd Wschodni”, 7 (2000) z. 1, s. 275-298. 
Dzwonkowski Roman, Represje wobec duchowieństwa katolickiego w ZSRR 1918-1939, w: „Skazani jako „szpiedzy Watykanu”. Z kościoła katolickiego ZSRR 1918-1956, red. R. Dzwonkowski, Ząki 1998, ss. 303.

Koprowski Marek, Kresy we krwi, Warszawa 2011.

Kurlandzki Stanisław, Danilecka Lilla, Panie, do kogoż pójdziemy? Marianie na Ukrainie, Warszawa 2001.

Mucha Jan, Organizacja diecezji kamienieckiej do 1795 r., „Roczniki Teologiczno-Kanoniczne", 30 (1983) z. 4, s. 61-284.

Odrodzenie Kościoła katolickiego w byłym ZSRR. Studia historyczno-demograficzne, red. E. Walewander, Lublin 1993.

Osadczy Włodzimierz, Kościół katolicki na Ukrainie wobec represji sowieckich, w: Represje wobec Kościoła w krajach bloku wschodniego. Komuniści wobec religii po 1944 roku, red. J. Marecki, Kraków 2011, s. 83-91.

Pasterz i twierdza. Księga jubileuszowa dedykowana biskupowi Janowi Olszańskiemu ordynariuszowi diecezji w Kamieńcu Podolskim, red. J. Wołczański, Kraków-Kamieniec Podolski 2001.

Polacy na Ukrainie. Zbiór dokumentów, cz. 1: lata 1917-1939, t. 1, red. S. Stępień, Przemyśl 1998.

Rosowski Witalij, Dzieje rzymskokatolickiej diecezji kamienieckiej w latach 1918-1941, Lublin 2008.

Słownik Geograficzny Królestwa Polskiego i innych krajów słowiańskich, t. 12, red. B. Chlebowski, Warszawa 1892.

Szpyczko Nela, Kościoły i sanktuaria. Ksiądz Władysław Wanags - budowniczy 29 kościołów rzymskokatolickich na Podolu, „Rota”, 1 (2004) s. 61-64.

Szpyczko Nela, Rożkow Władysław, Ojciec Władysław Wanags MIC - siewca żywej wiary na Podolu w okresie radzieckiego totalitaryzmu, w: Славістичні студія: лінгвістика, літературознавство, дидактика. Збірник наукових праць, ред. Н.В. Подлевска, Хмельницький-Люблін 2015, s. 257-258.

Szymański Józef, Rola Kościoła katolickiego i jego duchowieństwa na Ukrainie w zachowaniu wiary i tożsamości narodowej, „Archiwa Biblioteki i Muzea Kościelne”, 81 (2004) s. 327.

Гуменюк Станіслав, Хто ти є?..(Kim ty jesteś?...), Хмельницький 2002.

Карасєвіч Францішек, Спогади про душпастерську працю, „Studia Catholica Podoliae", 6 (2012) s. 435.

Пасічник Олег, Перший етап гонінь радянської влади щодо Римо-католицької Церкви на Поділлі 1918-середина 20-х років, „Studia Catholica Podoliae”, 6 (2012) s. 350351.

Схематизм. Камянець-подільська дієцезія під захистом Пресвятого Серця Господа Icyca, [Kamieniec Podolski 2001].

\section{Netografia}

Jak ksiądz Wanags kościoły budował, http://www.kresy.pl/publicystyka,reportaze?zobacz/jak-ksiadz-wanags-koscioly-budowal (dostęp: 9.03.2016) 


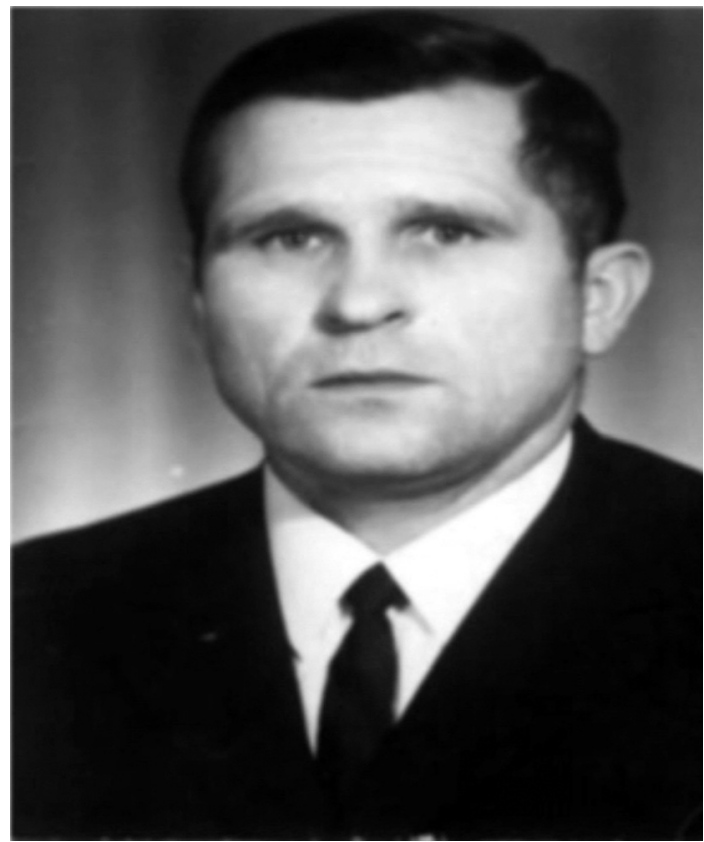

Fot. 1. Zdjęcie z dowodu osobistego W. Wanagsa, przed wstąpieniem do Seminarium Duchownego w Rydze. Lata 60. XX wieku.

Zbiory Archiwum Parafialnego w Gródku Podolskim.

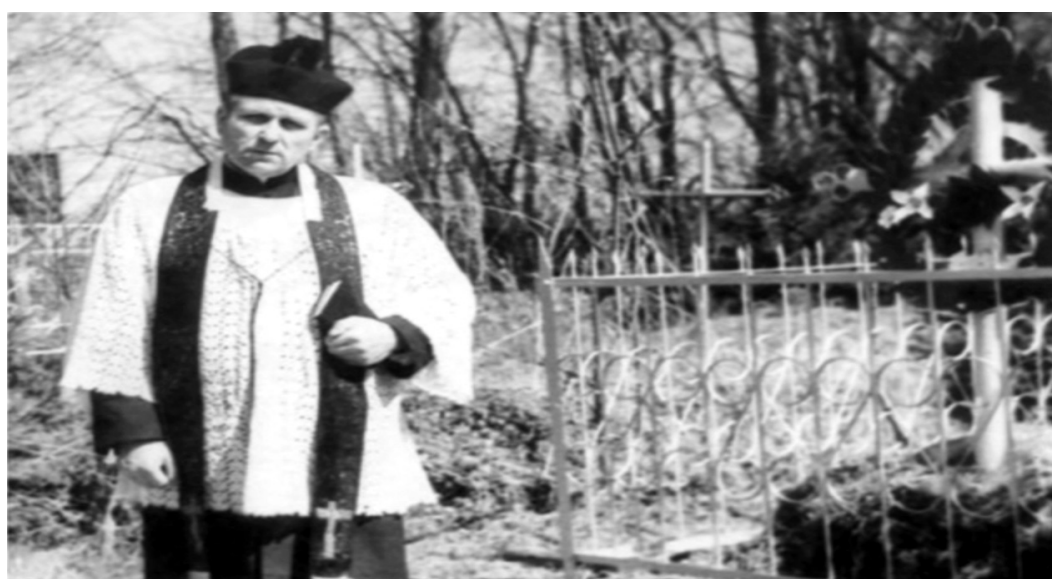

Fot. 2. Ks. W. Wanags na cmentarzu w Gródku Podolskim. Lata 70. Zbiory Archiwum Parafialnego w Grodku Podolskim. 


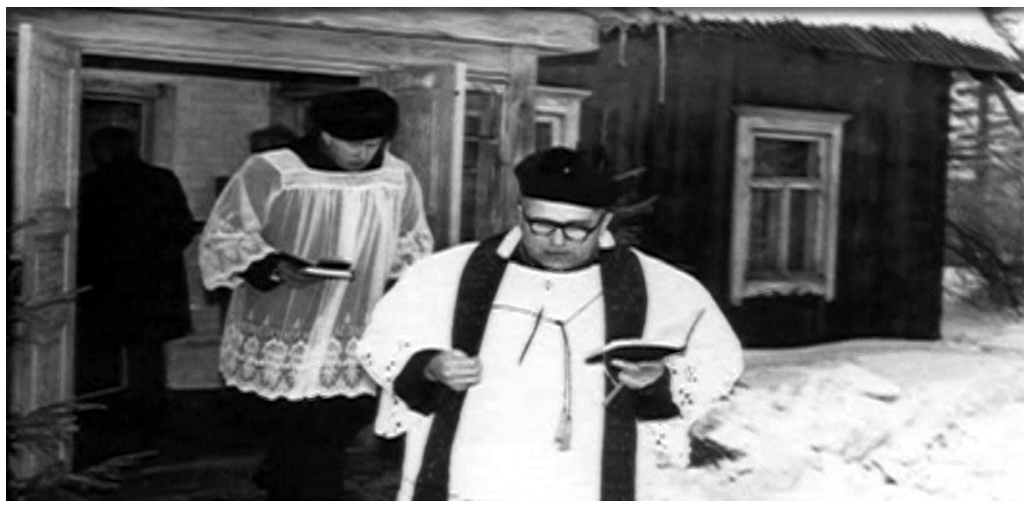

Fot. 3. Ks. W. Wanags podczas wizyty duszpasterskiej. Lata 80 . XX wieku. Zbiory Archiwum Parafialnego w Gródku Podolskim.

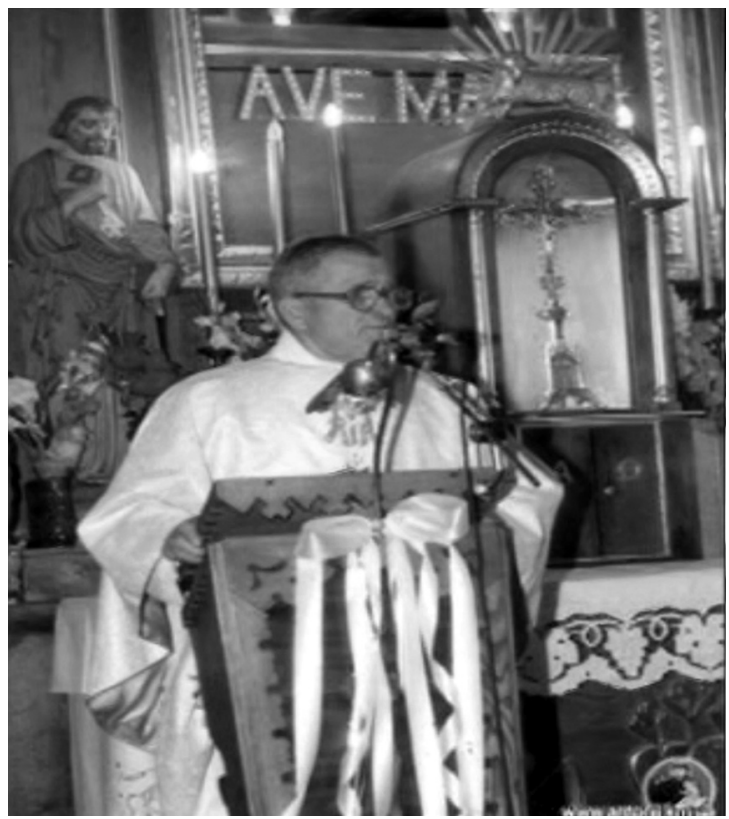

Fot. 4. ks. W. Wanags gloszący kazanie w kościele w Grodku Podolskim. Lata 90. XX wieku.

Zbiory Archiwum Parafialnego w Gródku Podolskim. 


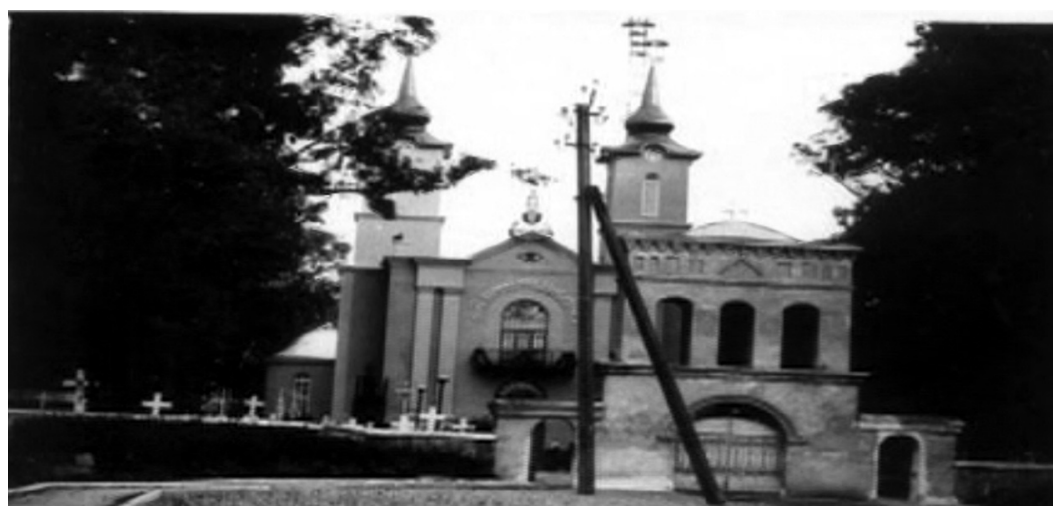

Fot. 5. Kościół parafialny pw. św. Stanisława BM w Gródku Podolskim. Lata 80. XX wieku. Zbiory Archiwum Parafialnego w Gródku Podolskim.

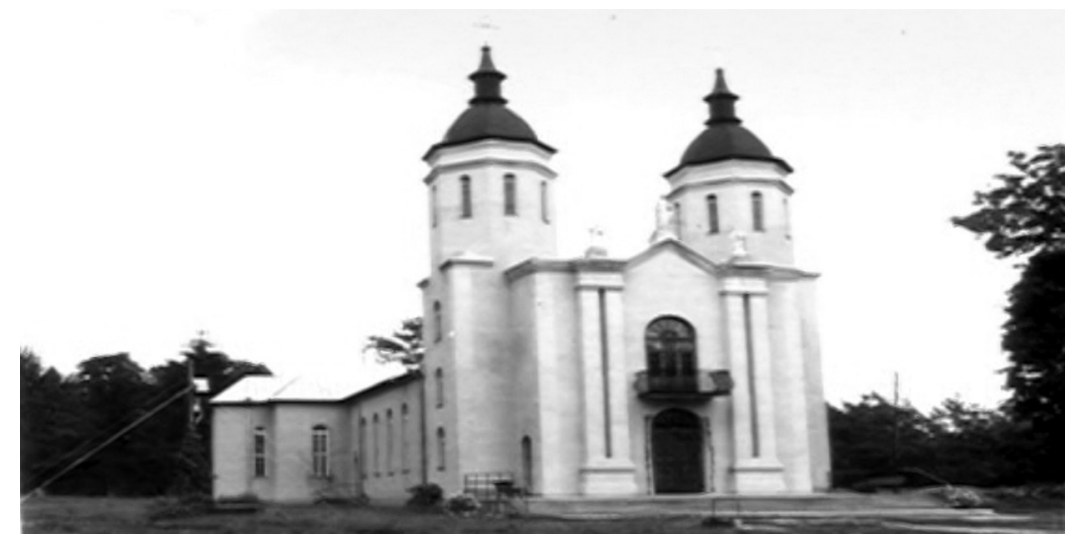

Fot. 6. Kościół parafialny w Tynnie pw. Wniebowzięcia NMP. Lata 90. XX wieku. Zbiory Archiwum Parafialnego w Gródku Podolskim,. 


\title{
REV. WLADYSEAW WANAGS MIC AND HIS WORK IN PODOLIA IN THE YEARS 1977-2001
}

\begin{abstract}
Summary
The article presents Rev. Władysław Wanags, a Marian priest, and his achievements. He was born in Latvia, but most of his life spent in Soviet Ukraine working among the Catholics in Podolia. As an adult, he experienced inner conversion, which resulted in the choice of the priestly life. After a brief ministry in Latvia, he was directed by the church authorities to work in Ukraine in 1971. He became famous for uncompromising nature and courage that won him the respect from the faithful and the local party apparatus. $\mathrm{He}$ worked strenuously and served the congregation at a time when the communist authorities fought with religion and obstructed pastoral work.

Rev. Wanags became famous as a great builder. He initiated and often actively participated in building twenty new churches, twenty-nine parish houses, two buildings for the seminary, a house for the poor and the elderly. All these buildings were erected within 10 years. He also managed to restore nine historic churches which had been ruined for decades. Even now the churches erected by him are called ,wanagsowe” because of their appearance.
\end{abstract}

Keywords: Władysław Wanags; Gródek Podolski; the Diocese of Kamyanyets and Podolia; the 20th century; Communism; USSR; Ukraine 